\title{
Os conceitos kantianos e a música
}

VICENTE DE PAULO JUSTI

UNICAMP (pkjusti@uol.com.br)

A filosofia kantiana da Terceira Crítica é rica em termos experiência estética. Tais termos apresentam, muitas vezes características conceituais próprias, algumas vezes inesperadas e frequentemente complexas. Pretende-se aqui verificar se a semântica dos conceitos kantianos da Terceira Crítica contribui para a compreensão da nossa atual experiência estética musical, em uma linha de análise semelhante à proposta na Semântica Transcendental de Kant proposta por Zeljko Loparic (2002).

\section{A sensibilidade, a sensação e o sentimento}

Howard Caygill (2000, p. 283), autor do importante Dicionário Kant, no verbete "sensibilidade", declara: " $A$ doutrina da sensibilidade de Kant, a qual desempenha um papel crucial na filosofia crítica, é um incômodo amálgama de numerosas formas de argumento mutuamente incompatíveis."

0 autor apresenta sua discutível conclusão baseado numa análise crítica histórica que, pela amplitude, escapa ao nosso interesse. Nosso objetivo é traçar a semântica conceitual da definição de sensibilidade e seus correlatos a partir da Crítica da Razão Pura (CRP), confrontá-la com o seu uso na Crítica da Faculdade do Juízo (CFJ) e tentar uma verificação em sua contribuição para nossa compreensão contemporânea do fenômeno estético.

0 primeiro problema apresentado é o limite entre sensibilidade e entendimento. A primeira é receptiva e o segundo apresenta-se como uma faculdade de julgar, "porque, consoante o que ficou dito, é uma capacidade de pensar. Ora pensar é conhecer por conceitos (CRP B94)." No entanto, Kant deixará claro que a sensibilidade não é somente uma porta aberta da nossa recepção nem somente uma tabula rasa 
passiva. Ao tratar dos dois troncos do conhecimento humano, sensibilidade e entendimento e reiterar que: "(...) por intermédio, pois, da sensibilidade são-nos dados objetos e só ela nos fornece intuições; mas é o entendimento que pensa esses objetos e é dele que provêm os conceitos (CRP B33)." Conclui que: "Na medida em que a sensibilidade deverá conter representações a priori, que constituem as condições mediante as quais os objetos nos são dados, pertence à filosofia transcendental (CRP B30)."

A sensibilidade não só não é uma mera porta de entrada das representações, como afasta-se muito disso. Ela não recebe todo e qualquer objeto, somente aqueles que nos podem ser dados, condicionados a representações a priori que constituem a própria sensibilidade. Nessas condições apriorísticas, ela pertence também à filosofia transcendental. Kant deixa também clara a interação entre sensibilidade e 10 entendimento. Uma vez que um objeto é recebido pela sensibilidade, o entendimento deve apresentar-lhe um conceito correspondente. "Pensamentos sem conteúdo são vazios; intuições sem conceitos são cegas (CRP A 51)."

$\mathrm{Na}$ Terceira Crítica, uma explicação sobre a sensibilidade encontra-se na explanação kantiana do sublime:

A sensibilidade é a porta de entrada de todos os sinais, informações e sensações que alteram nosso estado anterior. Em determinadas situações a sensibilidade é saturada pelo excesso, como no sublime (CFJ 99).

Caberá às faculdades do conhecimento uma elaboração desses dados para que o ânimo não entre em pânico ou desespero como ocorre na experiência do sublime.

Para o Kant da CFJ, a sensibilidade parece mais exclusivamente receptora, ao usar os termos porta de entrada. Em outros momentos da Terceira Crítica, a sensibilidade parece apresentar um sentido de receptora das representações, mas também participante, com as outras faculdades do conhecimento, de processos mentais elaborados, como quando Kant diz:

Porém a determinabilidade do sujeito por esta idéia e na verdade de um sujeito que em si pode na sensibilidade ter a 
sensação de obstáculos, mas ao mesmo tempo de superioridade sobre a sensibilidade pela superação dos mesmos, como modificação do seu estado, isto é o sentimento moral (CFJ 115).

A experiência estética musical é demasiado complexa para que nela possamos analisar separadamente a participação da sensibilidade. A participação das faculdades de conhecimento em um trabalho de retroalimentação imediata e concomitante com a experiência da audição molda a sensibilidade, dirige a atenção para detalhes, permite uma seletividade. Esses mecanismos permitirão outras audições com igual ou maior interesse por parte do ouvinte. Na experiência da estética musical, a sensibilidade é a porta de entrada, mas em que medida seu papel não é o de uma porta passiva e sim ativamente participativa, deve ser objeto de estudos posteriores.

\subsection{A sensação (Empfindung)}

A teoria da sensibilidade, como a "capacidade de receber representações graças à maneira de como somos afetados pelos objetos (CRP B34)" apresenta-se como um contínuo no pensamento kantiano, ao longo da CFJ. Não há alteração na base do mecanismo de nossa sensibilidade, isto é, o fato de que a conseqüência dessa alteração de estado leva ao conhecimento ou ao comprazimento; no primeiro caso, quando a representação corresponde a um conceito apresentado pelo entendimento e, no segundo caso, quando a ausência de conceitos leva as faculdades de conhecimento a um jogo das faculdades, à uma reflexão, e ao consequente comprazimento.

A sensação será, então, tudo o que nos afeta. Esse mecanismo inicial, Kant o chama de percepção (sensação mais consciência). A sensação é o efeito de um objeto sobre nós.

Não há na teoria kantiana do conhecimento a possibilidade da existência de um objeto que não nos afete. Tal hipótese não está nem ao menos pressuposta, pois a definição kantiana de sensação contém implicitamente a de objeto, algo que modifica nosso estado, referindo-se a nós como sujeitos que percebemos (CRP B377). 
Na Terceira Crítica, a sensação é apresentada com destaque na Introdução. Kant, ao explicar a validade lógica de um objeto e o que constitui a natureza estética de uma representação, propõe que ambas as relações surjam no conhecimento de um objeto dos sentidos, apresentando-se externamente a mim, isto é, no espaço. Assim:

A sensação (neste caso a externa) exprime precisamente o que é simplesmente subjetivo das nossas representações das coisas fora de nós mas no fundo, o material (real) das mesmas (pelo que algo existente é dado), assim como o espaço exprime a simples forma a priori da possibilidade da usa intuição (XLIII).

Esta citação, em relação à Primeira Crítica, corresponde exatamente (em parte) a "o espaço e o tempo são as formas puras desse modo de perceber; a sensação em geral a sua matéria (B60 e 157)", sendo a matéria o real da percepção, 12 enquanto referência ao conhecimento, isto é, como o que caracteriza a sensação sensorial, e nestas condições, é comunicada universalmente (CFJ 153). A possibilidade de transmissão universal é reiterada em CFJ 205, quando Kant esclarece que os três modos de expressão que unificam e constituem a comunicação completa do falante são pensamento, intuição e sensação.

A CRP apresenta definições de sensação que visam esclarecer seu papel no mecanismo da aquisição do conhecimento. Comparadas ao mecanismo da compreensão musical, podemos afirmar que a sensação, na música, será o som tomado isoladamente, ou conjunto de sons sem consideração da forma que os organiza. Em B 34 lemos que a sensação: "é o efeito de um objeto sobre a capacidade representativa, na medida em que por ele somos afetados." Isto é quase uma repetição de B377 em que a sensação: "é uma percepção que se refere simplesmente ao sujeito, como modificação do seu estado."

Nesta nossa tentativa de transpor as palavras de Kant para a nossa atual apreensão musical, encontramos ainda:

A apreensão, mediante a simples sensação, preenche apenas um instante (desde que eu não considere, é claro, a sucessão de várias sensações) [...] a sensação não tem pois grandeza 
extensiva [...] Assim, pois, toda a sensação e por conseguinte, toda a realidade no fenômeno, por pequena que seja, tem um grau, isto é, uma grandeza intensiva, que pode sempre ser diminuída (B 211).

Simples sensação seria um som isolado, que "preenche apenas um instante" e que faria parte de uma peça musical se eu considerasse "a sucessão de várias sensações." Se este som preenche apenas um instante, ele é uma sensação sem grandeza extensiva. Mas ele apresenta um grau, isto é, uma grandeza intensiva, propriedade que será utilizada na música com intensidade musical (piano, forte, fortíssimo e etc.). Assim, as sensações sonoras só serão percebidas musicalmente quando apresentarem a grandeza extensiva, o que é possível pela sucessão de sensações. Como a música é muito mais complexa do que a simples sucessão de sensações sonoras, o que constituiria no máximo, uma melodia simples, nota-se claramente uma analogia entre as condições de existência da música e do conhecimento. Isto é possível porque "Os três modos do tempo são a permanência, a sucessão e a simultaneidade (CRP B219)", o que vemos, constitui a base, o alicerce, da estrutura musical. Como Kant conclui no mesmo parágrafo, "essas três regras precedem toda a experiência e tornam-na possível." Assim, a base de constituição musical é a mesma dos três modos do tempo, mesmo porque a música ocorre no tempo. A base temporal, portanto, é comum ao conhecimento em geral e à música.

A teoria musical utiliza o termo percepção musical. A percepção kantiana, que na CRP é a consciência empírica, ou seja, uma consciência em que há simultaneamente sensação, será transposta à percepção musical ao considerarmos a percepção de diferentes sons, de diferentes alturas, a relação entre eles e mesmo as relações rítmicas. A percepção da música, não de simples sons, exige o ajuizamento reflexivo na forma e assim, neste caso, a expressão da música se confunde com apreciação musical. A percepção musical é uma experiência do fenômeno sonoro, mas não estética, pois não envolve contemplação, ajuizamento e prazer. 
A discussão de se uma mera sensação poderia ser música é reveladora em Kant, pois é proposta por alguém reconhecidamente desinteressado na causa musical,

(...) um simples som, como porventura o de um violino, é em si declarado belo pela maioria das pessoas, se bem que ambos (com a cor) pareçam ter por fundamento simplesmente a matéria das representações, a saber pura e simplesmente a sensação (CFJ § 14).

A verdadeira discussão é saber se a pura e simples sensação pode ser uma coisa bela. Aqui, no entanto, importa apenas saber em que condições um simples som, portanto uma simples sensação desprovida da forma, da reflexão, do jogo das faculdades poderia ser declarado belo e, se assim for, em que condições um simples som, uma sensação conteria forma, levaria à reflexão, não podendo então ser considerado mera sensação, já que esta é só a matéria das representações.

Podemos acrescentar que a maioria das pessoas declarará belo um simples som de violino porque o reconhecem como possível parte da música, e essa influência as levará a não tomá-lo como um simples som desconectado da música e, portanto apenas como sensação. Um simples som vindo do momento da afinação do violino, por exemplo, não será considerado belo. Mais adiante, Kant admite que: "então cor e som não seriam simples sensações, mas já determinações formais da unidade do múltiplo dos mesmos e neste caso poderiam ser também contados por si como belezas." A razão desta afirmação é que Kant observa, com Euler, que sons resultam de vibrações do ar. Kant chega a indagar se estas vibrações apresentam uma verdadeira forma, mas não responde essa pergunta. Essa base física poderia levar à vivificação do órgão e à reflexão? Alinhamo-nos ao Kant formalista em nossa tentativa de fundamentar a beleza musical, enquanto vemos a forma como a organização dos sons e tendemos a não concordar com o Kant que se aventa a possibilidade de um simples som (simples sensação) poder ser reconhecido como belo, pois, ainda que se admita que o som resulta de uma superposição de estruturas ondulatórias, e como tal tenha uma forma descrita por equações matemáticas, essa superposição de ondas não nos é diretamente perceptível e muito menos somos capazes de discernir os detalhes de sua 
estrutura. 0 que aqui se torna promissora é a discussão resultante já que, se aqui Kant admite a possibilidade de um simples som ser belo, em outros trechos da CFJ apresenta a música como um todo como agradável.

Nossa conclusão, quanto a problemática levantada pela simples sensação, é que esta não pode ser considerada bela, pois não pode haver forma em sensações isoladas. As vibrações que constituem "determinações formais da unidade do múltiplo dos mesmos" não poderiam nem ao menos atingir o simples nível das sensações. Não há possibilidade, pois, de que simples sensações provoquem reflexão sem a forma que só se manifesta em várias sensações concomitantes ou sucessivas, de alguma maneira estruturadas.

\subsection{0 sentimento (GefühI)}

Sentimento (Gefühl) designa uma resposta da mente humana ao ser afetada por um objeto. Não diz respeito às propriedades dos objetos. Isto pode ser a principal característica da diferença entre sentimento e sensação. A sensação mantém relações diretas com o objeto, entendendo-se como objeto o que é externo a nós e, assim, ocorre no espaço.

Simplificadamente, sensação é o que nos afeta, sentimento é a nossa reação mental frente à sensação. Veremos que Kant desenvolve com sutis complexidades essa relação.

Peter Kivy em sua obra "Introduction to a Philosophy of Music" apresenta um capítulo intitulado "Emotions in the Music". Em seu início, afirma haver um crescente consenso entre filósofos da música de que faz sentido descrevê-la em termos expressivos, o que contraria a famosa tese de Hanslick. Kivy (2002, p. 30) declara:

Como o consenso geral é que, quando nós dizemos que uma passagem da música é plena de tristeza ou amedrontadora, ou como tal, nós não estamos descrevendo uma disposição da música para surgir tal emoção em nós, mas atribui-se tal emoção como uma propriedade percebida na própria música.

0 artigo segue a linha emocionalista, que podemos considerar oposta à interpretação formalista que pretendemos 
dar à teoria estética kantiana. Ao citar Hanslick, Kivy faz-lhe justiça, pela posição adotada por aquele na interpretação formalista da estética musical. A utilização do termo "expressão" é que torna a proposta problemática. Deve haver uma concordância geral de que música seja expressiva. Os intérpretes musicais, os maestros, todos são a sua maneira, expressivos. É expressivo quem expressa algo. Os formalistas dirão que a música expressa a si mesma. 0 problema é que Kivy qualifica as expressões como alegria, tristeza, medo, etc. como intrínsecas da música. Esta opção de interpretação da música tem como consequência o dever de se apresentar onde e como estes sentimentos são apresentados na música e, principalmente, se há correlação e coerência entre autores diferentes e a experiência dos mesmos sentimentos. Ou seja, como seria a alegria em Bach, em Mozart e assim por diante, e se haveria característica musicológica na escrita da alegria, por exemplo.

Kivy (2002, p.54) acrescenta comentários como: "como todas as explanações filosóficas de Kant, é notória a dificuldade de compreensão." Pode-se concluir que a filosofia kantiana não é o interesse do autor.

O sentimento é considerado como um "dos mais ambíguos e portanto mais fascinantes conceitos de Kant" (CAYGILL, 2000, p. 288). Não é objeto de nosso estudo o conceito de sentimento em todo o Kant, mas somente nas relações apresentadas com o seu uso na CFJ.

Já nas Observações sobre o sentimento do belo e do sublime, Kant afirma que:

(...) diferentes sensações de contentamento ou de desgosto repousam menos sobre a qualidade das coisas externas que as suscitam, do que sobre o sentimento próprio a cada homem, de ser por elas sensibilizado com prazer ou desprazer (KANT, 1993, p. 19).

Inicia-se assim a grande questão do fundamento do sentimento. Se situado nas qualidades das coisas externas, teríamos a predominância do empirismo, se situado no sujeito, não haveria diferença entre os objetos, pois qualquer coisa poderia causar qualquer sentimento, já que este não 
dependeria da coisa. Este problema é aprofundado no exemplo dado por Kant (1993, p. 20) do "corpulento":

(...) gente corpulenta, para quem o autor mais espirituoso é o próprio cozinheiro e para quem as obras do gosto refinado encontram-se na própria adega, terá, nas obscenidades comuns e em um gracejo inconveniente, a alegria tão intensa quanto aquela da qual tanto se orgulham pessoas de nobre sentimento.

Tratado de maneira irônica por Kant, o trecho oculta um grande problema. Se o que importa é o sentimento, permanece a questão de que o mesmo sentimento pode ocorrer por razões muito diferentes como o exemplo citado da "alegria tão intensa" pela comida e vinho ou por outras razões por pessoas de nobre sentimento. Nesta primeira parte, aparentemente, Kant classifica os sentimentos de acordo com as pessoas que os sentem.

Sua classificação, no entanto, assume bases mais consistentes ao qualificar os sentimentos que não são "saciados" nem "extenuados", pressupondo uma sensibilidade da alma (é o início da ligação com o mundo prático?) com talentos e qualidades do entendimento (o que ocorrerá na CFJ pela forma) e que "aqueles primeiros sentimentos (do corpulento) podem ocorrer mesmo na completa ausência do pensamento", o que é o primórdio de uma divisão que na CFJ dará origem ao agradável. Assim, o sentimento refinado considerado na dupla espécie do sublime e do belo, definitivamente diferencia-se da "alegria intensa" do glutão.

Na CRP, em B830, Kant afirma em uma nota ${ }^{1}$ que prazer ou desprazer enquanto conceitos práticos, reportam-se

1 "Todos os conceitos práticos se reportam a objetos de satisfação ou de aversão, isto é, de prazer ou desprazer, portanto, pelo menos indiretamente, a objetos do nosso sentimento. Mas como este não é uma faculdade representativa das coisas, antes reside fora de toda a faculdade cognitiva, os elementos dos nossos juízos, na medida em que reportam ao prazer ou desprazer, por conseqüência, à filosofia prática, não pertencem ao conjunto da filosofia transcendental, que tem simplesmente que ver com conhecimentos puros a priori (KANT, CRP, p. 637)." 
a objetos dos nossos sentimentos e, como essa faculdade não é cognitiva, não pertenceriam ao conjunto da filosofia transcendental. Que Kant tenha escrito a CFJ pode ser entendido como uma revisão dessa declaração, levando-se em conta que, na Primeira Crítica, Kant não trata de prazer e desprazer em seu uso estético de valor equivalente ao conceitual, o que ocorrerá apenas na Terceira.

Na CFJ, a utilização conceitual de sentimento é sempre enquanto sentimento de prazer ou desprazer, resultado de reflexão sobre a forma. No entanto, a passagem de sensação para sentimento não é um caminho fácil. Kant reconhece que "se uma determinação do sentimento de prazer ou desprazer é denominada sensação (CFJ 9)", então expressa algo muito diferente da sensação enquanto representação de um dado dos sentidos, referindo-se ao objeto do conhecimento e referindose à pessoa na determinação do prazer ou desprazer. Assim, em 18 alguns casos, o termo "sensação" pode ser usado em referência a pessoas, como Kant elucida no mesmo trecho:

(...) entendemos, contudo, pela palavra sensação uma representação objetiva dos sentidos; e [...] queremos chamar aquilo que sempre tem que permanecer simplesmente subjetivo e que absolutamente não pode constituir nenhuma representação de um objeto, pelo nome aliás usual de sentimento.

O exemplo kantiano para explicar esta diferença é o das cores. A cor verde dos prados é a sensação objetiva, o agrado que produz pertence à sensação subjetiva.

O principal ponto a notar na definição do sentimento de prazer ou desprazer é a atuação da faculdade do juízo, independentemente de conceitos e sensações (CFJ LVI), um prazer da simples reflexão (CFJ 155).

Um exemplo ocasional que mostra a natural ambigüidade dos termos "sensação" e "sentimento" ocorre em 155 da CFJ:

(...) lá, porém, (no julgamento estético) simplesmente para perceber a conveniência da representação com a ocupação harmônica (subjetivamente conforme a fins) de ambas as faculdades de conhecimento em sua liberdade, isto é, ter a sensação de prazer no estado da representação. 
Apesar da excelência dessa tradução da Terceira Crítica, pode-se permitir uma rápida visualização neste trecho, que fala em "sensação de prazer", uma vez que o original diz: "d.i. den Vorstellungszustand mit Lust zu empfinden" isto é: "sentir prazer com o estado de representação." Empfinden é nosso verbo "sentir" e também a raiz para Empfindung, a nossa "sensação". Quando se fala em prazer, como resultado de uma experiência, espera-se um sentimento. Mas como, o prazer pode ser imediato, sem muita elaboração de nossa mente, falarse em sensação de prazer também apresenta nexo.

No Prólogo, ao investigar se a faculdade do juízo contém princípios a priori, se são constitutivos ou regulativos e "se ela fornece a priori a regra ao sentimento de prazer e desprazer enquanto termo médio entre faculdade do conhecimento e a faculdade da apetição (Pról. V)", Kant explica a própria razão de ser da CFJ e assim a insere no sistema crítico transcendental. Neste momento, o sentimento de prazer e desprazer assume um status crítico que o colocará como parte dos "julgamentos que se chamam estéticos e dizem respeito ao belo e ao sublime da natureza ou da arte (Prol. VIII)."

Este status crítico do sentimento de prazer/desprazer está ligado ao mecanismo de funcionamento das faculdades de conhecimento. Há uma concordância entre a natureza, ao nos fornecer uma multiplicidade de objetos e o entendimento, ao encontrar conceitos para estes objetos. No caso dos objetos belos, de que trata a CFJ, o entendimento não encontra a lei que possa levar ao conceito. Assim: "a realização de toda e qualquer intenção está ligada com sentimento de prazer (CF), § VI xxxix)" e a condição da realização é uma representação a priori, que neste caso é um princípio para a faculdade de juízo reflexiva em geral. Do mesmo modo, o sentimento de prazer é "determinado mediante um princípio a priori e legítimo para todos (CFJ, § VI - xxxix)." Assim, no mecanismo de encontro das percepções com as leis, não há necessidade de intenção por parte do entendimento, que age em função da natureza, e temos o conhecimento que é a própria concordância entre eles.

Mas a descoberta da possibilidade de união de duas ou várias leis da natureza sob um princípio que integre ambas "é razão para um prazer digno de nota" (CFJ, § VI - xxxix). 
Outro desenvolvimento desta questão ocorre no $§ 12$ da CFJ. Kant esclarece que não podemos estabelecer a conexão de sentimento de prazer ou desprazer como "um efeito, com qualquer representação (sensação ou conceito), como sua causa (CFJ 36)", pois relações de causalidade são conhecidas $a$ posteriori, através da experiência.

O escritor e crítico musical Eduard Hanslick (18251904), nascido em Praga, filho de um entusiástico filósofo e músico é o grande defensor de uma estética formalista musical, pela sua pequena mas contundente obra "Do belo musical" (1854). Não declara em seus escritos se foi influenciado pela Terceira Crítica de Kant, mas suas idéias e sua citação do nome de Kant entre o de outros filósofos permitem-nos concluir que ele devia conhecer bem a filosofia kantiana. A citação nominal de Kant refere-se aos filósofos que defendem "a falta de conteúdo na música" que segundo Hanslick (1989, p. 153), 20 partindo de pensadores não músicos teria mais coerência, pois aqueles procuram a verdade e não interesses próprios. Entre as citações do livro "Do belo musical" destaca-se:

0 que se deveria comprovar aqui, de forma puramente teórica, é se a música tem a capacidade de representar um sentimento determinado. A resposta é negativa, já que a precisão dos sentimentos não pode ser dissociada de representações concretas e de conceitos e estes se encontram fora do domínio constitutivo da música (HANSLICK, 1989, p. 34).

A opção por uma interpretação formalista é clara no questionamento da capacidade da música de representar sentimentos determinados. Espera-se, portanto, por uma definição do belo musical, que fornece o título de sua obra (HANSLICK, 1989, p. 61):

É um belo especificadamente musical. Com isso entendemos um belo que, sem depender e sem necessitar de um conteúdo exterior, consiste unicamente nos sons e em sua ligação artística. As engenhosas combinações de sons encantadores, seu concordar e opor-se, seu afastar-se e reunir-se, seu elevase e morrer - é isto que, em formas livres, se apresentam à contemplação de nosso espírito e que dá prazer enquanto belo. 
Hanslick nos dá uma descrição do que chamamos estrutura musical, que constitui a forma da obra. Sua mais conhecida frase, da mesma obra é: "O conteúdo da música são formas sonoras em movimento (HANSLICK, 1989, p. 62)" sendo o conteúdo as próprias notas "de que se compõe uma peça musical, e que, enquanto partes dela, constituem um todo" (HANSLICK, 1989, p.154).

\section{A comoção (Rührung)}

A riqueza de sentimentos humanos é o que permite sua classificação. 0 texto kantiano leva a essa constatação, apesar de Kant não apresentar uma taxonomia criteriosa. A comoção é tratada como sensação (Empfindung) e não como sentimento (Gefühl). Isto é notável, pois, enquanto sentimento é fundamentado no sujeito e não no objeto, esperar-se-ia aqui que fosse tratado como sentimento. Por outro lado, um critério também usado nos textos é que o sentimento é sempre o sentimento de ou por algo, assim, estamos com raiva de alguma coisa ou estamos tristes por alguma coisa. Dado que a comoção não apresenta essa ligação motívica Kant preferiu classificá-la como sensação interna: "Comoção, uma sensação em que o agrado é produzido somente através de inibição momentânea e subseqüente efusão mais forte da força vital, não pertence absolutamente à beleza" (CFJ 43).

A última parte da frase, a separação entre comoção e beleza, revela o Kant formalista que vê na experiência da beleza o sereno comprazimento na forma do objeto e não encontra lugar para sentimentos pessoais e subjetivos. A comoção está distante do comprazimento, que tem como fundamento a reflexão sobre a forma. Esse sentimento advém de um juízo de gosto puro, sem atrativos nem comoção, isto é, sem "nenhuma sensação enquanto matéria do juízo estético" (CFJ 43). Vemos aqui o Kant totalmente formalista, pois a comoção não pode pertencer à beleza e o sentimento de prazer ou desprazer tem uma ligação cognitiva através da forma.

Esta conclusão é problemática para os dias em que vivemos, quando o poder de comover tornou-se parâmetro de 
qualidade artística. ${ }^{2}$ Kant deixa claro que há sentimento diferentes sempre relacionados a alguma experiência. Não se pode encontrar, a partir da constituição humana, uma taxonomia psicológica destes. Para Kant, a comoção tira a pureza do juízo de gosto se estiver misturado ao fundamento de determinação do mesmo (CFJ 39). Entretanto, a comoção não é vista por ele como totalmente negativa. Ela pode "tornarse forte até ao afeto" (CFJ 122).

Nesse sentido, temos comoções fortes e comoções ternas. As ternas levam ao sentimentalismo, execrado por Kant, pois indicam "uma alma doce e ao mesmo tempo fraca" (CFJ 122). A comoção aceita por Kant é de duas espécies; uma ligada à admiração dos fins da natureza e outra que leva ao sublime. As primeiras, "assim como a comoção mediante tão múltiplos fins da natureza, que um ânimo ao refletir está em situação de sentir, (...) possuem sem si algo de semelhante a um sentimento 22 religioso" (CFJ 478, nota 19). Percebemos a elevação da comoção, tida na definição como sensação ao nível de sentimento e, mais ainda, religioso. A segunda é a comoção forte, fundada em preceitos morais: "a prescrição rigorosa do dever", "pelo respeito pela honra da humanidade em nossa pessoa e pelo direito dos homens" (CFJ 123). Esta comoção forte nos permite a experiência do sublime. Kant inclui aí a desolação, não a tristeza deprimente, "se tiver o seu fundamento em idéias morais" (CFJ 128). Foram estas considerações de Kant sobre as relações entre a comoção forte e seu fundamento nas leis morais, que nos levaram a crer que podemos falar em música sublime.

\section{0 afeto (Affekt)}

$\mathrm{Na}$ explicação da aquisição de nosso conhecimento, Kant na Primeira Crítica (B74) havia tomado os objetos como nos sendo dados. Há uma sensação que pressupõe a presença real do objeto e, por isso, para ele, a sensação é a matéria do

\footnotetext{
${ }^{2}$ Hoje a comoção vende produtos e atesta qualidade artística de todas as formas de arte nos meios de comunicação. Um estudo crítico da questão encontra-se em Lacroix (2006).
} 
conhecimento sensível. No caso dos objetos belos não se efetua este mecanismo que leva ao conhecimento. Somos afetados igualmente por objetos externos a nós, que alteram nosso estado interior. A faculdade da imaginação, sendo também uma faculdade produtiva, reage à presença do objeto, e sua reação é uma representação, em nós, do objeto apresentado. Dependendo de como nosso ânimo é afetado, podemos classificar essa representação como afeto. 0 afeto em nós, frente a um objeto, é uma representação criada pela nossa faculdade da imaginação.

Vimos que, para Kant, a comoção pode "tornar-se forte até ao afeto" (CFJ 122). Vimos também que a comoção é uma sensação. A partir desses caminhos apresentados por Kant, podemos tentar uma definição de afeto: uma comoção fortificada, isto é, uma comoção que distancia-se da sensação que a originou e se aproxima do sentimento. Kant dirá que os afetos "são impetuosos e impremeditados e inibem a liberdade do ânimo" (CFJ 121, nota 7) ao explicar a diferença entre eles e as paixões, que pertencem à faculdade de apetição e são, portanto, inclinações. Assim, confirma Kant, os afetos referemse meramente ao sentimento.

0 afeto será dividido em gênero vigoroso e gênero lânguido e, assim, as comoções que se tornam fortes até ao afeto são também fortes ou ternas (CFJ 122). A denominação para o âmbito das comoções ternas é o sentimentalismo. Kant, normalmente um severo escritor que evita exemplos, neste caso, preenche toda uma página para abominar as inúmeras espécies de comoções fracas como a dor fingida, males fictícios, espetáculos chorosos, falsa humildade e até preleções religiosas. As comoções fortes fundamentam-se no dever, na honra e na humanidade presente em nós. Os afetos fortes nos levarão ao sublime, os outros poderão proporcionar "um gozo do bem-estar proveniente do restabelecido equilíbrio das diversas forças vitais em nós" (CFJ 124), não sendo, assim, totalmente inúteis.

O entusiasmo, para Kant, é um exemplo de como "o ânimo eleva-se sobre certos obstáculos da sensibilidade através de princípios morais" (CFJ 121). 0 entusiasmo será a idéia do bom acompanhada de afeto, um "estado de ânimo a tal 
ponto sublime que comumente se afirma que sem ele nada de grande pode ser feito" (CFJ 121). Mesmo elevando o entusiasmo ao mais alto grau na escala dos afetos, Kant considera que ele não promove a reflexão e, portanto não pode trazer um comprazimento da razão. Entretanto, o que nos importa muito mais é que "esteticamente, contudo, o entusiasmo é sublime, porque ele é uma tensão das forças mediante idéias" e isto o torna mais poderoso e duradouro que o impulso por representações dos sentidos. A segurança kantiana está sempre no ajuizamento que através de conceitos leva ao conhecimento. Há razões a priori, portanto transcendentais, para uma valorização das experiências estéticas. Tudo o que envolve emoções, sentimentos ou afetos é visto com certa desconfiança por Kant, dado o terreno inseguro em que se movem por dizerem respeito a reações pessoais subjetivas de difícil universalização, a conotações de interesse, 24 enfim, por serem distantes da lógica. Entende-se por que o entusiasmo surge como o afeto mais privilegiado: por sua ligação com o bom, e não pelo seu componente afetivo.

Além desta transformação da sensação em comoção e deste em afeto, encontramos em Kant uma outra. Na "Untersuchung über die Deutlichkeit der Grundsätze der natürlichen Theologie und der Moral" [Nat. Theol. 4. Btr § 2 (V 1, 145) Vol I Kant Werke], citado por Eisler no verbete "Gefühl" (p.175) lemos:

Pois começou-se a compreender em nossos dias que a faculdade de representar a verdade é o conhecimento, mas a única que percebe o bom, é o sentimento, e que ambas não devem ser confundidas uma com a outra.

A importância deste enunciado kantiano repousa na valorização do sentimento, que adquire status de faculdade (Vermögen). Da mesma forma que o mesmo sentimento é valioso na CFJ, sendo então um sentimento nos leva à reflexão e à consciência da beleza, e também com status de faculdade do prazer e desprazer, trata-se na citação da faculdade de perceber o bom.

Assim, o sentimento credencia-se como o elo de ligação nas relações entre a sensibilidade e a música, o que 
possibilitará a divisão estética da música em agradável, bela e sublime, a ser detalhada nos respectivos capítulos.

A música não pode ser explicada como uma sensação única. É um complexo imenso de sensações e o que torna a nossa percepção uma experiência estética, mesmo da música mais simples, não são as sensações enquanto tais, mas a forma como estas sensações estão organizadas, formando uma estrutura que denominamos uma peça musical.

Os sentimentos proporcionados pela música compõem um enorme e fascinante capítulo da sua história, a ponto da mais difundida definição de música ser "a linguagem dos sentimentos." Os pensadores sensualistas tendem a acreditar que a música carrega semanticamente conceitos emocionais e afetivos. Já a classificação kantiana permite basear a música agradável na sensação, incluir o sentimento de prazer ou desprazer da música bela fundado na forma (exige, portanto, uma cognição pelo menos parcial) num complexo jogo das faculdades, que abrange a reflexão, a contemplação, o desinteresse, a universalidade, e dispensa os atrativos, as emoções, as comoções e os conceitos.

Durante o período barroco da música (1600-1750), os afetos constituíram-se num arcabouço teórico conhecido na Alemanha como "Affektenlehre", a teoria dos afetos.

Acreditava-se que determinadas tonalidades, acordes, células rítmicas e melódicas, utilização de certos instrumentos musicais, etc. seriam capazes de transmitir determinadas emoções, sentimentos, afetos, como alegria, tristeza, raiva e ódio. Esta teoria dos afetos barroca, não encontraria obstáculos à sua compreensão na teoria estética kantiana, desde que não se tome a música barroca como bela, como a vemos hoje. 0 seleto grupo de frequentadores dos eventos musicais da época teria criado uma espécie de código semântico adicional à música, que na época era uma música funcional, isto é, a serviço de algo que não a mera bela contemplação própria das salas de concertos modernas. Nesses casos, este algo era a música a serviço da palavra, para realçar, confirmar o sentido do texto. A beleza da música estaria em sua capacidade de conduzir os ouvintes à compreensão das mensagens propostas. 
O jogo das faculdades kantiano estava na percepção desta capacidade da música de realizar tal transmissão, e o comprazimento na própria compreensão. Não se tratava, portanto, de uma experiência estética kantiana da beleza. A faculdade da imaginação identificava os afetos em estruturas musicais conhecidas, e o entendimento aceitava esta identificação. A mensagem aceita pelo entendimento age como um conhecimento compreendido e adquirido no momento da apresentação musical. A faculdade da imaginação em sua capacidade produtiva agregava os conceitos dos afetos nas estruturas musicais reconhecidas pelos ouvintes. A memória deveria exercer um papel preponderante neste reconhecimento, pois os compositores deveriam utilizar de células musicais semelhantes para afetos semelhantes.

Assim, na época imediatamente anterior a Kant e mesmo durante sua educação há uma preparação e 26 encaminhamento do pensamento estético para um entendimento sensualista da música. Esta não só carrega mensagens afetivas, mas mensagens específicas e determinadas. Kant ao colocar a emoção em seu devido lugar, e propor o importante papel da forma, em sua teoria estética, engrandece-se de maneira ainda não avaliada por seus estudiosos.

A comoção na audição musical ou em qualquer fenômeno artístico contemporâneo é só aparentemente problemática. Kant é simples e direto, não há espaço para atrativos e comoções na experiência estética do belo. Há uma parte cognitiva importante representada pela forma. A experiência da beleza é contemplativa, e emoções em geral não fazem parte do comprazimento estético. As emoções comovedoras só são importantes para Kant se fizerem parte da experiência do sublime e a comoção no sublime só é aceitável se ligada ao mundo prático moral. A única possibilidade de aceitação da comoção na experiência estética é que o sujeito, ao experimentar o sublime, se veja refletido nessa experiência, se veja como humano destinado à vocação moral. Essa vocação moral de que o homem kantiano se auto-imbui, é o que se materializa na experiência do sublime. 
O entusiasmo é o grande afeto kantiano, e também é a grande qualidade esperada de um músico. Se, como Kant disse "nada de grande pode ser feito sem entusiasmo" (CFJ 121), podemos adicionar: principalmente na música. Esse afeto diz respeito principalmente ao intérprete musical. Sua capacidade expressiva na realização musical está relacionada diretamente ao seu entusiasmo na execução. 0 entusiasmo é uma das qualidades imprescindíveis do bom músico.

\section{0 prazer (Lust)}

O termo prazer perpassa inúmeras vezes as obras kantianas com semântica localizada. A Antropologia, a Metafísica dos Costumes e a Crítica da Faculdade do Juízo são as principais. Na Antropologia aparece a distinção entre prazer/desprazer sensorial e intelectual, causados por sensação ou imaginação, e conceitos ou idéias representáveis. Na Metafísica dos Costumes ocorre também a discussão sobre os prazeres/desprazeres intelectuais. 0 mesmo tópico reaparece na CFJ, que Caygill (2000 p. 257), chama de "seu grande tratado sobre o prazer."

Na CRPr (2002, p.15) na nota 19 do Prefácio, Kant afirma que:

Vida é a faculdade de um ente de agir segundo leis da faculdade de apetição. A faculdade de apetição é a faculdade do mesmo ente de ser, mediante suas representações, causa da efetividade dos objetos destas representações. Prazer é a representação da concordância do objeto ou da ação com as condições subjetivas da vida. (...) Nota-se facilmente que a questão, se o prazer tem de ser posto sempre como fundamento da faculdade de apetição, ou se também sob certas condições ele somente se segue à determinação dela, fica mediante esta elucidação pendente (...).

A mesma questão pode-se colocar na CFJ, ou seja, se o sentimento de prazer é o fundamento do juízo do belo ou se, sob certas condições, ele se segue à determinação da reflexão ou do jogo das faculdades do conhecimento, como conseqüência destes fatos. 
Ocorrem inúmeras referências ao prazer ao longo da CFJ que exigem um estudo aprofundado; sua importância na ligação entre faculdade do conhecimento e apetição, a conexão com a lei moral e com o conceito de conformidade a fins da natureza, a função do entendimento nesse processo estético (uma vez que o prazer não faz parte do conhecimento e por isso não diz nada do objeto), a validade universal nos dias atuais tão influenciada pela cultura, o prazer no sublime, como caracterizar diferentes prazeres para o agradável, o belo e o sublime, a comunicabilidade do prazer, e assim por diante.

Na Antropologia, Kant afirma:

A sensibilidade nas faculdades de conhecimento (a faculdade de representação na intuição) contém duas partes: os sentidos e a faculdade da imaginação. 0 primeiro é a faculdade da intuição na presença do objeto, a segunda também sem a presença do mesmo. Os sentidos, porém, são divididos em sentidos internos e externos. 0 externo é aquele em que o corpo humano é afetado através das coisas corpóreas, o interno, em que é afetado pelo ânimo; pelo que se deve observar que o último (interno), como simples faculdade da percepção (da intuição empírica), do sentimento de prazer e desprazer, quer dizer, a predisposição do sujeito de determinar-se através de uma representação, para a manutenção ou alteração do estado desta representação, é pensado diferentemente do que se poderia denominar no sentido interior. Uma representação através do sentido, que como tal se pode evidenciar chamase sensação.

Tomando-se a explicação kantiana do funcionamento da sensibilidade nas faculdades de conhecimento, podemos entender que a percepção musical ocorre de acordo com as duas partes propostas por Kant. Através da audição recebemos os sons como sensações sonoras. A organização (forma) desses sons, um após outro, formando uma melodia, os sons simultâneos que formam a harmonia musical, a distribuição no tempo, que constitui a pulsação e ritmo, a diferença de intensidade (crescendo e decrescendo, piano e forte), tudo isto é constituinte da obra musical. Só podemos dizer que ouvimos música quando esses sons musicais se destacam do conjunto dos sons que costumeiramente ouvimos na natureza, e por sua organização (forma) nos chamam a atenção e alteram o estado 
de nosso ânimo. Kant já havia afirmado na CRP que a sensibilidade "é a receptividade de nossa capacidade de conhecimento sendo afetada de alguma maneira pelo fenômeno" e que "sentimentos de prazer e desprazer e a vontade não são conhecimentos." Ora, para Kant, somente o conhecimento através de conceitos é um verdadeiro conhecimento, mas o próprio Kant desenvolve um complexo mecanismo de ajuizamento reflexivo, que envolve as faculdades de conhecimento (sendo um juízo, envolve especialmente o entendimento), mas o juízo reflexivo não é conhecimento. 0 entendimento, sendo a faculdade não sensível do conhecimento, irá reconhecer na música tudo o que não é sensível, isto é, tudo o que na composição musical pertence à organização e à estrutura. A música sequer poderia ser um conhecimento por meio de conceitos, uma vez que não é discursiva, mas o que a música tem de organização em sua forma é equivalente ao que o entendimento utiliza dos conceitos para formular juízos.

Se, para o conhecimento, tenho duas fontes, a saber, o recebimento de impressões das representações e a capacidade de conhecer objetos mediante as representações, na percepção musical tenho algo semelhante: um recebimento das impressões sonoras e uma capacidade de reconhecer a forma, isto é a organização que produz o jogo das faculdades e conseqüentemente o prazer. Neste sentido, fica claro que a música não é para ser pensada, pois não há conceitos, a não ser no sentido musicológico de seu estudo. Se a percepção da forma na música é empírica, como a experiência da percepção dos sons, ou pura, é uma questão que deverá ser vista sob a ótica da teoria kantiana do gênio. Esse mecanismo não deve ser diferente do mecanismo do conhecimento conceitual devendo haver nele elementos puros e elementos empíricos.

Como dito anteriormente, pode-se verificar, em Kant, uma pequena taxonomia das paixões, incluindo-se aqui todo tipo de sentimento, sensação, etc. Deleite é um prazer pelos sentidos e que como diverte, pertence ao agradável. Inversamente, a dor, que também é desprazer pelos sentidos é desagradável. Elas não se relacionam como aquisição e falta, mas como aquisição e prejuízo, mais e menos ( $\$ 57$ da CFJ). São esses os diferentes sentimentos apresentados por Kant: 
Rührung - comoção; Gefühl - sentimento; Reiz - atrativo; Empfindung - sensação. No § 16 da Antropologia, continua Kant:

Podemos dividir os sentidos da sensibilidade corporal em sensibilidade vital (sensus vagus) e sensibilidade orgânica (sensus fixus). (...) Pertencem ao sentido vital a sensibilidade do calor e frio, mesmo aqueles que advêm pelo ânimo, como por exemplo a alteração rápida entre esperança e medo. 0 horror que extravasa pela representação do sublime nos homens e o cruel, onde as fábulas faziam as crianças correr para as camas nas noites, são do último tipo, eles penetram no corpo tão longe quanto neles está a vida (KANT, 2006, p. 53).

O sublime é valioso não pela sensação, mesmo porque a sensação de medo está entre as mais básicas. Este sobrepujar o medo e entender a superioridade da destinação humana sobre o que o causa, com a vitória da vida, constitui parte do motor que leva os homens ao sempre desejado e esperado progresso moral e o desenvolvimento contínuo da cultura (ciência e arte).

Ainda na Antropologia (parágrafo 18 - "Da audição"):
o sentido da audição é um dos sentidos de percepção
simplesmente mediata. (...) A forma do objeto não é dada
pelo ouvido e o som da fala não dirige imediatamente para
uma representação; são, porém certamente por causa disso, e
porque ele em si nada significa, menos ainda algum objeto,
que, em todo caso, sejam somente sentimentos internos, que
de melhor maneira só ocorre por meio da indicação do
conceito, por isso os nascidos surdos permanecem também
mudos e não conseguem obter nada análogo à razão (KANT,
2006, p. 54).

Kant sempre afirma que a forma é a responsável pelo conhecimento que possamos ter do objeto, o que ocorre com a aplicação do conceito. No parágrafo acima, ele nega qualquer possibilidade de representação pela audição, por entender que os conceitos só podem ser transmitidos quando ouvimos a palavra correspondente ao seu conceito. Supõe-se que a linguagem de surdos-mudos não havia ainda sido desenvolvida. Na realidade, o único campo de conhecimento em que a forma pode ser transmitida pela audição é a música, 
desconsiderando-se aqui que um músico excepcionalmente experiente consiga apreender a integridade dos elementos constantes na partitura apenas pela observação visual. Trata-se de uma experiência possível, mas não equivalente à experiência da audição musical.

Sobre a audição e a música, continua Kant no parágrafo 18 da Antropologia:

Mas, o que corresponde ao sentido vital, este assim vem através da música, como um jogo regular da sensibilidade do ouvido, indescritivelmente vivo e de movimento de muitas maneiras não simples mas também fortalecedor, que também da mesma forma é uma linguagem da simples sensibilidade (sem conceito). Os sons são aqui tons e isto para o ouvido corresponde à cor para a visão; uma comunicação do sentimento no distante espaço, para todos que o encontram e um prazer, que com isso não diminui os muitos que dela tomam parte (KANT, 2006, p. 55).

Kant repete aqui o que disse muitas vezes na CFJ, ou seja, que a música é um jogo, mas da simples sensibilidade, o que somente pode classificá-la como agradável. Os termos "Sprach" "linguagem", "an alle" "para todos", utilizado por Kant podem levar a problemas, pois uma linguagem da simples sensibilidade não deveria levar a uma comunicação do sentimento e ao prazer. Como comunicação do sentimento e prazer ocorrem, o fenômeno não pode pertencer à simples sensibilidade. Assim Kant não pode estar aqui tratando da música agradável, mas da bela.

Ainda na Antropologia, (Zweites Buch - Das Gefühl der Lust und Unlust -Einleitung), lê-se:

1) Os sensoriais. 2) 0 prazer intelectual. 0 primeiro ou através do sentido (deleite) ou através da faculdade da imaginação (o gosto); o segundo (na realidade intelectual) temos ou pelo conceito apresentado ou pelas idéias, e assim também o contrário, que apresenta o desprazer (KANT, 2006, p. 127).

Aqui Kant parece ter avançado em relação à CFJ ao considerar que os sentidos tomam parte na faculdade da imaginação pelo gosto. Na CFJ, o gosto é apresentado como juízo do belo, onde os sentidos são importantes apenas como 
caminho inicial para se chegar à forma, a verdadeira razão da beleza. Tomados isoladamente, os sentidos são tidos como receptores dos atrativos, e pouco considerados. Encontramos a explicação mais elaborada nas Duas Introduções:

Prazer é um estado da mente, no qual uma representação concorda consigo mesma, como fundamento, seja meramente para conservar esse próprio estado (pois o estado de poderes da mente favorecendo-se mutuamente em uma representação conserva a si mesmo) ou para produzir seu objeto. No primeiro caso, o juízo sobre a representação dada é um juízo de reflexão estético. No segundo, é um juízo estético patológico ou estético-prático (KANT, 1995, p. 67).

Nota-se claramente a denominação juízo estéticoprático, o que nos permite admitir a experiência estéticaprática, do agradável e, posteriormente, a experiência inteiramente prática do sublime.

32 Listowel (1954, p. 81) afirma que, como Kant sustenta, o gozo estético da arte ou da natureza é um gozo essencialmente contemplativo, o que implica numa certa distância entre o eu e o objeto que se aprecia na contemplação. Como os prazeres do esporte e do jogo derivam imediatamente de nossa própria atividade e esforço, devem ser excluídos da esfera estética. Além disso, Kant afirma repetidamente que o prazer estético é desinteressado, o que exclui então o que é útil, o agradável e o erótico, da esfera do belo. Se levarmos o rigor kantiano como se deve, o intérprete musical, instrumentistas e maestros, no momento de execução musical, não participam da experiência estética que eles mesmos proporcionam aos ouvintes. Não apresentam o devido distanciamento para uma perfeita contemplação. 0 prazer do intérprete musical, por mais intenso e profundo que seja, é de outra natureza, ainda não definida. Se caminharmos com Kant por todo o caminho proposto por ele mesmo, poderíamos dizer com Kant, que idéia é um princípio existente como algo espiritual (geistlich) que se expande no mundo material. Com Cassirer (1948, p. 326) explicando Kant, a idéia é o arquétipo espiritual do artista dentro de si mesmo. Este se impõe à matéria e a transforma em unidade e forma. Pode-se afirmar que a teoria kantiana da produção artística é idealista (no sentido original platônico) e a apreciação estética da beleza é formalista. 


\section{A forma (Form)}

A importância da forma no estudo da estética, em contraposição com um conteúdo emocional na obra de arte, faz com autores como Gatz, tenham dificuldade em classificar Kant entre estas duas linhas. Em sua obra de 1929 o autor apresenta uma extensa lista das principais direções seguidas pela estética musical após Kant. Realiza uma grande divisão entre a música como arte heterônoma e autônoma. Entende que Kant apresenta-se em duas possibilidades de classificação, a de sensualista e a de formalista. No capítulo I denominado "Dogmatische Inhaltsästhetik (Estética dogmática do conteúdo) na sub-seção "Sensualistische Richtung (Corrente sensualista) e no II Capítulo "Formästhetik - negative Inhaltsästhetik (Estética formal - estética negativa do conteúdo). As duas correntes estéticas musicais - a formalista e a sensualista - são reciprocamente excludentes. A primeira afirma que a música contém os sentimentos que transmite e a segunda que a música não é transmissora de sentimentos, mas apresenta forma e que esta forma é seu próprio conteúdo.

A admissão de que Kant, em sua teoria estética, consegue atender às duas linhas simultaneamente o torna um filósofo obrigatório no estudo destas questões. Encontramos na Dissertação de 1770 a preocupação kantiana de definir matéria, forma e a sensibilidade do sujeito frente a estes dois conceitos. Por matéria entende-se "as partes que são tomadas aqui como sendo as substâncias" e precisamos saber "como é possível que várias substâncias se possam juntar numa unidade (KANT, 1985 p. 36)." Não se constitui, um problema concordarmos que a música contém sua matéria, o som, e que este tem suas partes, isto é suas propriedades, que entendemos aqui como correspondentes ao termo kantiano "substâncias". Apesar da dificuldade de se conceituar a música como um objeto (alguns acham que seria mais um evento ou processo que um objeto), não vemos aqui grandes problemas, pois o objeto kantiano é complexo o suficiente para poder incluir a música como tal. Se a matéria da música é tudo o que é sonoro, o conjunto de tudo o que pertence ao som como substrato básico, e a forma é a maneira pela qual podemos conhecer o objeto, não há 
como conhecer o objeto musical separando-o em suas partes, isto é, separando o conjunto dos sons da maneira de ouvi-los. Está implícita na definição de música que se trata de um conjunto de sons organizados ou estruturados em alguma forma.

0 que queremos demonstrar é que podemos identificar partes da música, segundo o esquema kantiano de matéria, forma, percepção de uma unidade em várias substâncias que se juntam, mas não podemos falar de música se separarmos essas partes. A música é percebida como uma unidade composta, mas o sentido musical está na unidade.

Na primeira parte da Estética Transcendental, $\S 1$ da CRP lemos: "Forma é o que possibilita que o diverso do fenômeno possa ser ordenado segundo determinadas relações." Claramente entendemos que o fenômeno se nos 34 apresenta sob várias facetas. Não há uma única apresentação para um determinado fenômeno. Essas apresentações diferenciadas são o que Kant chama de diverso. Apesar dessas diferenças de apresentações, há algo comum entre elas, que é o que nos permite ordená-las e reconhecer que sob diferentes apresentações, temos na verdade o mesmo fenômeno. 0 comum às apresentações é a forma. Não que tenham a mesma forma, mas o fato de apresentarem uma. Árvores apresentam a forma de árvore apesar da diversidade de formatos arbóreos, assim como a música apresenta forma musical, apesar das múltiplas possibilidades de estrutura sonora.

Na CFJ lemos: "o formal na representação de uma coisa, é a concordância do múltiplo com o uno (seja qual for)" (KANT, 1992b, p. 46). Com outras palavras, Kant repete sua definição de forma. Esta é o que permite que várias aparências estejam em concordância com uma unidade contida no objeto apresentado. Ainda na CRP lemos que a forma é: "a relação entre os conceitos dados" e "a maneira como os elementos constitutivos estão ligados numa coisa (B 322)", ficando claro que estes elementos constitutivos são a matéria do fenômeno. Tratamento semelhante encontra-se na Lógica: "Devem-se distinguir em cada conhecimento matéria, 
isto é, objeto e forma, isto é maneira como conhecemos o objeto" (KANT, 1999, p. 69).

Vemos então que a forma kantiana é uma moeda de duas faces. Uma face está no objeto, em sua propriedade de apresentar-se em sua diversidade e uma outra face, no sujeito, que é capaz de perceber esta diversidade do objeto e notar uma unidade nesta diversidade e, através deste processo, conhecer o objeto. Para que isto seja possível, devemos possuir a "forma da intuição", uma estrutura subjetiva da sensibilidade que precede toda a matéria (as sensações). Segundo Kant (CRP B322) a forma é precedida pela matéria no conceito do entendimento puro, mas o entendimento puro não pode referir-se imediatamente a objetos (pois o tempo e espaço não são coisas em si), eu, sujeito, devo ter em mim a forma da intuição. A matéria nos é apresentada numa multiplicidade, e só concluímos que esta multiplicidade contém uma unidade formal, porque estamos aparelhados antes de toda apresentação, com a estrutura subjetiva de nossa sensibilidade.

Em poucas palavras, só percebemos objetos cuja forma estava em nós a priori. Em termos musicais, os sons existem como matéria (talvez possamos aqui dizer, matéria-prima) na natureza. Que o múltiplo dos sons ou o diverso dos sons (sensações) pudesse se constituir numa unidade chamada música, estava em nós, antes mesmo de sabermos que os sons existiam. Uma interpretação não kantiana poderia dizer que, a cada experiência sonora, os homens aprenderam a juntar, ordenar e combinar sons, e que, portanto, o aprendizado musical é totalmente empírico. Esta, naturalmente não é a vertente de nosso estudo.

Pierre Bourdieu não apresenta análises da música em Kant em sua obra "La Distinction", mas suas observações acerca da CFJ são dignas de comentários. $\mathrm{Na}$ análise entre forma e atrativo, no caso uma explanação sobre a fotografia, o autor afirma:

Entre todas as características próprias à imagem, somente a cor (que Kant tinha como menos pura que a forma) pode determinar a suspender a rejeição de fotografias como insignificantes. Nada é mais estranho, com efeito, para a consciência popular que a idéia de um prazer estético que 
para falar como Kant, seria independente do agrado das sensações (BOURDIEU, 1979, p. 44).

A distinção kantiana entre o atrativo das sensações do agradável e a forma do belo é utilizada para classificar experiências. A forte experiência da forma leva o ouvinte à experiência do belo, apesar da presença intrínseca do atrativo das sensações. Não se trata de desconsiderar o poder das sensações, trata-se da força da forma. Se o atrativo for dominante ou se o sujeito não estiver apto a perceber a forma, mesmo que esta esteja presente, o objeto será agradável para esse sujeito. Para Kant, o que deve ficar claro é que a experiência da beleza depende da percepção da forma. Se a forma estiver acompanhada de atrativos, como o timbre na música, ainda assim a experiência será da beleza.

Uma interpretação do texto kantiano sobre a beleza, no qual podemos identificar e incluir o fenômeno musical, 36 encontra-se em Kulenkampff (in ROHDEN, 1992, p. 15):

A natureza de um objeto, que perfaz a sua beleza, é a sua forma ou a sua configuração (Gestalt). Ela é, mais precisamente, o que Kant denomina forma da conformidade a fins de um objeto ou conformidade a fins sem fim (CFJ $\mathrm{p}$. $34,44,48$ e 58). Com isso se pensa na estrutura de uma totalidade perfeitamente integrada, na qual todas as partes ou elementos combinam de tal maneira ou formam um todo de maneira que não se pode omitir nem acrescentar nada sem destruir a totalidade. Tudo combina e se integra como se estivesse sido organizado com vistas a fins.

Ao observarmos o fenômeno musical, concordamos acerca da existência de uma estrutura, um todo integrado, no qual não temos o direito de intervir sob o risco de sermos acusados de termos destruído a obra, ou, na melhor das hipóteses, de termos criado uma outra obra, mesmo ainda que baseada na anterior, uma obra que apresentará as mesmas características de partes ou elementos formadores de uma unidade que deve igualmente ser respeitada. Esta perfeita combinação e integração de elementos dá-nos a idéia de conformidade com vistas a algo que não precisa ser explicado: é a conformidade a fins sem fim kantiana. 
Kulenkampff (in ROHDEN, 1992, p. 16) vai além ao afirmar que: "A forma da conformidade a fim é uma qualidade objetiva do objeto, pois ela lhe cabe ou não indiferentemente se alguém sabe disso ou não, se alguém percebe isso ou não."

Então podemos afirmar que é a forma que dá o caráter cognitivo à experiência estética, pois ela está objetivamente inserida no objeto, independente de nossa capacidade de percebê-la. Uma conformidade a fim sem fim é uma conformidade não amparada por conceitos explicativos, mas nem por isso menos cognitiva. É o que encontramos em alguns trechos da CFJ, em que Kant explica que "se o prazer estiver ligado à simples apreensão da forma de um objeto da intuição" (CFJ, Int. XLIV) o que deve ocorrer sem relação com conceitos, e, essa representação se liga não ao objeto, mas apenas ao sujeito. No mesmo trecho, mais adiante, afirma: "no caso de se ajuizar a forma do objeto (não o material da sua representação como a sensação) na simples reflexão sobre a mesma, como o fundamento de um prazer" o julgamento incluirá uma necessária ligação da forma no objeto, promovendo uma validade universalmente válida e o objeto em questão será considerado belo.

Parece claro que o objeto apresenta uma forma e apresenta o material de sua representação. 0 importante é que ajuizemos sobre a forma, que é o que poderá levar à atribuição da beleza, e deixemos de lado, as sensações transmitidas com o objeto, que não concernem ao ajuizamento sobre a beleza. Nos dois exemplos kantianos temos a apreensão da forma. No primeiro, simples apreensão da forma e, no segundo, ajuizamento da forma na reflexão. Isto resolve um grande problema da classificação da música enquanto agradável, pois não se pode falar em música sem forma, mas com Kant podemos falar em forma que é meramente apreendida, sem a necessária reflexão que fundamenta a beleza.

Em outros momentos da mesma Crítica, a forma parece ser a maneira como os objetos nos são dados. Este é o caso do $\S$ 17 "Do ideal e beleza", onde Kant trata da impossibilidade da determinação da beleza através de conceitos. Esta tentativa enganosa, explica Kant, ocorre porque há uma possível comunicabilidade universal da sensação e, com isso, do 
respectivo comprazimento ou descomprazimento com esta comunicabilidade.

Este fato permite-nos supostamente pensar que haveria nesta universalidade um "fundamento comum a toda a humanidade no julgamento das formas sob as quais lhes são dados objetos" (CFJ 53). Kant apresenta assim não um objeto com forma característica, mas maneiras diferentes dos objetos nos serem apresentados, e o julgamento seria, então, das formas desta apresentação. Se mais uma vez, utilizamos o texto kantiano para tentar compreender a música, concluiremos que não há diferença entre as duas possíveis interpretações do texto: uma interpretação da forma do objeto, ou, como prefere Kant, da forma da representação, e, outra, da forma como somos afetados pelo objeto ou pela representação.

Só podemos ser impressionados pela música se a recebermos e entendermos como música. Não é possível que haja uma maneira de sermos afetados pela música e uma outra maneira de a apreciarmos. Quando somos afetados por ela é porque pudemos recebê- la como música, e então a compreensão da forma da música e a consciência da forma de como somos afetados por ela se sobrepõem, pois não poderíamos ser afetados sem a percepção de sua forma. É a forma da música que nos permite ter consciência de como somos afetados. Se na música agradável ocorre uma simples apreensão da forma, sem reflexão, rigorosamente não se pode falar em apreciação estética.

Numa comparação entre Kant e Schopenhauer, Bourdieu (1979, p. 567) chama de "privilégio que Kant fornece à forma, mais pura, em detrimento da cor e de sua sedução quase carnal" o que estabelece diferenças entre o belo e o bonito (jolie) e como Kant diferencia plaisir de jouissance (prazer de alegria) e beau et agreable. Através de Schopenhauer, Bourdieu reconhece a taxonomia kantiana do belo e do agradável sem deixar de aplicar uma escala de valores às duas experiências, coisa que nem Kant faz.

Refere-se também à conhecida citação kantiana de que a música ocupa o último lugar entre as artes (BOURDIEU, 1979, p. 572 - nota 12), não mencionando que o contexto kantiano 
desta classificação éque a música, sendo uma arte agradável, está, nesta classificação, abaixo das artes belas.

Isto não a torna uma arte pior que as outras, mas significa apenas que, tomando-se certo critério (a presença da forma), a música não ocupa um lugar entre as artes formais. Se escolhermos um trecho da CFJ em que Kant cogita a possibilidade da música ser bela, a classificação citada deixaria de ter sentido.

A denominação de formalista que atribuímos à teoria estética kantiana encontra um claro apoio em afirmações como a que "é um erro comum e muito prejudicial ao gosto autêntico, incorrompido e sólido, supor que a beleza atribuída ao objeto em virtude de sua forma, pudesse ser aumentada pelo atrativo" (CFJ 41). 0 rigor kantiano estabelece as condições na relação entre forma e beleza, mesmo nos objetos da natureza pois "o belo na natureza concerne à forma do objeto, que consiste na limitação" (CFJ 75). Diferencia-se assim do sublime que, além de não apresentar forma, é ilimitado.

É na relação entre forma e beleza de objetos da natureza que encontramos uma clareza maior deste problema, nas expressões "as formas belas da natureza" (CFJ 166) e "a verdadeira exegese da linguagem cifrada pela qual a natureza em suas belas formas nos fala figuradamente" (CFJ 170). São dois exemplos não só dessa clareza de idéias sobre a beleza da natureza como de uma indisfarçável admiração de Kant, sugerindo até uma intenção da natureza a nos dizer algo através de suas belas formas. Isto se verifica na Crítica da Faculdade de Juízo Teleológica, onde Kant declara que há razões para aceitar "a priori" que a natureza em seus produtos apresente formas específicas, adequadas, como que dispostas para a nossa faculdade do juízo: "Tais formas, através da sua multiplicidade e unidade, servem para simultaneamente fortalecer e entreter as faculdades do ânimo (que estão em jogo) às quais por isso atribuímos o nome de formas belas" (CFJ 267). Quando Kant utiliza o termo "servem", poderíamos entender que ele propõe uma finalidade nas formas da natureza, que serviriam para nos fortalecer e para entreter nossas faculdades. 
Posso entender que as formas da natureza não possuem uma ligação de finalidade conosco e que somos nós que estamos aptos a receber as belas formas da natureza e, com isso, termos nossas faculdades fortalecidas e entretidas. A finalidade, assim, estaria em nós, uma finalidade que conseguimos nos dar, na mesma medida em que nos damos as leis morais, por exemplo. Esta interpretação é baseada também em CFJ 172: "pelo menos interpretamos assim a natureza mesmo sem intenção desta."

As ocorrências de comentários sobre a forma na CFJ são mais numerosas quando Kant trata das formas dos objetos da natureza do que quando trata de objetos da arte. Na medida em que somos igualmente produtos da natureza, esta nos utiliza para a produção artística, o que, em última instância, permite dizer que os produtos da arte também são produtos da natureza e assim tudo o que Kant diz sobre a natureza, vale 40 para a arte.

Numa discussão sobre a importância que os atrativos podem exercer sobre a percepção da forma, Kant afirma: "os atrativos na natureza bela, que tão frequentemente são encontrados como que amalgamados com a forma bela, pertencem ou às modificações da luz (na coloração) ou às do som (em tons)" (CFJ 172). No original, Kant utiliza as palavras "des Schalles (in Tönen)" no final do trecho.

Depois de tantas afirmações de que o essencial no ajuizamento da beleza é a forma, e que as sensações que a acompanham devem ser desconsideradas, Kant reconhece que os atrativos podem estar amalgamados (zusammenschmelzend) à forma bela. Em palavras muito simples, diríamos hoje, que as cores das flores fazem parte da beleza destas, pois, nos seria muito complicado apreciar as flores pelas formas, sem dúvida, muito ricas, abstraindo-se de suas cores. 0 mesmo diríamos dos pássaros, que diferentemente das flores apresentam formas mais semelhantes entre si, mas combinações de cores tão divergentes quanto atraentes. Outro caso admitido por Kant é o das modificações do som em tons.

Como dito acima, ele utiliza duas palavras distintas Schall e Ton, respectivamente som e tom. Schall é o som no sentido físico, das vibrações que o produzem e Ton é o som 
considerado nas diversas possibilidades de altura, isto é, o som musical. Pois Kant nos diz que estas (cores e sons) são as únicas sensações que, pertencendo meramente ao sentimento sensorial, podem levar-nos à reflexão sobre a forma de como somos modificados por elas.

A apreciação musical, sendo uma experiência sensorialmente muito mais complexa do que apreciar flores e pássaros, apresenta nos atrativos, (timbre, por exemplo), um amalgamado de improvável separação. Não temos meios de ouvir um solo musical tocado pelo corne-inglês com o distanciamento que nos permitiria apreciarmos exclusivamente a forma (estrutura) da música, esquecendo-nos de qual instrumento o toca. Se isso fosse possível, o mesmo solo poderia ser tocado por flauta doce ou marimba ou qualquer outro instrumento e ainda assim teríamos nossa apreciação da beleza musical de idêntica maneira.

A questão é que aprendemos a ouvir o atrativo amalgamado com a forma, como reconhece Kant. A estrutura musical, ou forma atingiu um grau de complexidade, que não nos permite percebê-la separadamente dos atrativos que na verdade fazem parte desta forma. 0 próprio Kant nos ajuda, ao reconhecer que: "o atrativo das cores ou dos tons agradáveis" podem vivificar o objeto, ser-lhe acrescido e podem tornar a forma "mais exata, determinada e completamente intuível" e até "manter a atenção sobre o objeto" (CFJ 42).

Baseando-se na proposta kantiana de que o sentimento de prazer é devido ao "jogo livre da imaginação", Listowel (1954, p. 25), inclui Kant no capítulo intitulado "A teoria do jogo", em sua História Crítica da Estética Moderna. Na mesma obra, mais adiante afirma "Aunque la estética kantiana no es em modo alguno uniforme em su actitud hacia lo bello, en parte por lo menos parece ser definitivamente formalista" (LISTOWEL, 1954, p.139).

Nos parágrafos 42 e 43 da CFJ, falando sobre a forma, Kant afirma: "Toda forma dos objetos dos sentidos é ou figura ou jogo." Se é jogo no espaço, é jogo de figuras, como a mímica e a dança. Se é jogo no tempo é jogo das sensações. É uma das poucas referências ao tempo que Kant faz nesta Crítica. Alguns estudiosos da estética musical o criticam por isso. 
Compreende-se sua despreocupação com o tempo, especialmente o tempo musical, se considerarmos que toda experiência artística de maneira direta, como na música, ou indireta, frente a uma obra plástica, envolve tempo.

Kant, na CFJ $§ 14$ [42] afirma que:

Na pintura, na escultura, enfim em todas as artes plásticas, na arquitetura, na jardinagem, na medida em que são belasartes, o desenho é essencial, no qual não é o que deleita na sensação, mas simplesmente o que apraz pela sua forma que constitui o fundamento de toda a disposição para o gosto. As cores que iluminam o esboço pertencem ao atrativo; elas na verdade podem vivificar o objeto em si para a sensação, mas não o tornar digno de intuição e belo.

Esta interpretação kantiana estaria em perfeito acordo com o que pensamos a respeito da música, se ele a tivesse incluído. Se retirarmos da música seus atrativos, permanece na 42 composição musical o que corresponde ao desenho (estrutura e organização).

Se o juízo de gosto puro só pode ocorrer verdadeiramente com a estrutura e organização musicais, pergunta-se se é possível realizar um juízo totalmente puro, pois, na música, o atrativo (o timbre) está tão ligado à música que é freqüentemente confundido com a própria beleza. Alguns compositores escreveram a mesma obra para diferentes formações de instrumentos. Cada uma destas versões é recebida como uma obra diferente da outra. 0 que podemos afirmar é que o fundamento do juízo de gosto puro é a estrutura e organização da composição (que é a mesma, independentemente das versões), mas uma apreciação musical não ocorrerá somente com o juízo de gosto puro.

0 gosto contemporâneo não consegue ser somente puro, porque há uma confusa percepção do prazer, de tal forma misturada com os atrativos que não se vê como separar o que é puro do impuro e, sem levarmos em conta o intérprete, que por si só já é uma outra questão. No trecho citado acima (CFJ § 14), chama a atenção a importância que Kant deu à jardinagem, incluindo-a entre as belas-artes. Vemos duas razões principais para a classificação kantiana: a primeira, que a jardinagem em sua época tratava de formas geométricas nos jardins, o que 
eleva o trabalho a um nível quase conceitual e a segunda que a jardinagem significava uma alteração na natureza, um poder exercido pelo homem para a produção da beleza, o que certamente o encantava.

Giordanetti entende o conceito kantiano de que o essencial na arte bela repousa sobre a forma, ao afirmar que com esta definição kantiana, a forma é Grundlage der Kultur "a base da cultura".

\section{A conformidade a fins e sem fim (Zweckmässigkeit)}

Estes conceitos kantianos não são problemáticos para o estudioso da estética filosófica, pois é compreensível e aceitável que as artes não apresentem finalidade. A questão é que a explicação kantiana destes temas é mais complexa do que se entender finalidade como utilidade.

Kant afirma na CRP que "a ordem e a finalidade na natureza devem ser explicadas por razões naturais e segundo leis naturais" (B801). Isto é, não se encontra fora da natureza a explicação para a relação entre objetos e fins destes mesmos objetos.

$\mathrm{Na}$ CFJ o problema assume aspectos ainda mais densos, pois não se trata ali de objetos do conhecimento. Na Introdução, ao expor os princípios da faculdade do juízo reflexiva, Kant define "fim" como "o conceito de um objeto, na medida em que ele ao mesmo tempo contém o fundamento da efetividade deste objeto" (CFJ XXVIII). A definição do objeto deve conter uma explicação deste que me permita compreendê-lo integralmente.

Definir música simplesmente como conjunto de sons organizados não é aceitável, porque falta a menção a um fim. Neste exemplo, o fim da música é a inclusão, em sua definição, de algo que me diz respeito como sujeito que a experimenta. A organização sonora dirá respeito ao sujeito se esses sons organizados se apresentarem numa conformidade tal que meu 
juízo reflexivo sobre esta conformidade me traga um certo tipo de prazer. Então a música estará conforme a fins, pois esta conformidade "é o acordo de uma coisa com aquela constituição das coisas, que somente é possível segundo fins" (CFJ XXVIII).

Assim, o conjunto de sons estruturados é um objeto que não apresenta fins determinados. 0 sujeito percebe esta conformidade de maneira subjetiva, já que apresenta uma forma cuja conformidade leve ao prazer/desprazer não é algo inerente ao objeto, como Kant elucida: "Ora a conformidade a fins de uma coisa, na medida em que é representada na percepção, também não é uma característica do próprio objeto (pois esta não pode ser percebida)" (CFJ XLIII). Esta necessária participação do sujeito explica por que o objeto "só pode ser designado conforme a fins" (CFJ XLIII), pois é necessário que o sujeito tenha prazer nessa representação. Se esse prazer na 44 representação se apresenta ligado à simples apreensão, "sem relação da mesma com um conceito destinado a um certo conhecimento" (CFJ XLIII) então é apenas um prazer da adequação do objeto às faculdades do conhecimento, e a conformidade a fins é subjetiva. 0 objeto de minha representação será nesse caso agradável. Se o prazer é julgado "como necessariamente ligado", pois ajuízo a forma do objeto e esta é o fundamento do prazer na representação do objeto, o objeto é belo, e essa associação ocorre "para todo aquele que julga em geral" (CFJ XLV).

No $\S 10$ da CFJ Kant desenvolve a conformidade a fins em geral. Esta pode referir-se a um objeto, um estado de ânimo ou também uma ação (CFJ 33). ${ }^{3}$ Sua possibilidade passa a ser

3 "Conformidade a fins, porém, chama-se um objeto ou um estado do ânimo ou também uma ação, ainda que a sua possibilidade não pressuponha necessariamente a possibilidade da representação de um fim, simplesmente porque a sua possibilidade somente pode ser explicada ou concebida por nós na medida em que admitimos no fundamento da mesma uma causalidade segundo fins, isto é, uma vontade, que a tivesse ordenado desse modo segundo a representação de uma certa regra. A conformidade a fins sem fim não tem causas na vontade mas a deduzimos da vontade para compreendê-la." (CFJ § 10) 
explicada se admitirmos a vontade que passa a fundamentar a conformidade a fins, se houver uma causalidade segundo fins. Se não a houver, nossa conformidade será sem fim; neste caso não é necessária a participação da razão na experiência de recebermos uma representação de um objeto para percebermos uma conformidade a fins segundo sua forma, sem um fundamento final. 0 fundamento da conformidade continua sendo o prazer e sua denominação conformidade a fim sem fim.

Para que o objeto belo apresente uma conformidade a fins objetiva, ele teria que apresentar utilidade e perfeição (CFJ 44). Se o objeto belo apresentasse utilidade, o prazer teria ligação com esta utilidade e não seria um prazer imediato, mas posterior ao seu uso. A perfeição do objeto belo não pode ser aceita porque perfeição é um conceito, e o ajuizamento do belo ocorre pela conformidade subjetiva formal e não como um juízo de conhecimentos, por meio de conceitos. A conformidade a fins sem fim da música é a nossa constatação de que a estrutura sonora está apta a nos proporcionar prazer ao ouvila. 0 conceito "perfeição" não tem como adequar-se a ele.

\section{A Intuição (Anschauung)}

0 conceito kantiano de intuição não apresenta similaridade com o sentido utilizado de pressentimento ou achado sem explicação que, às vezes, utilizamos. Com esta ressalva, a intuição kantiana não é problemática em sua compreensão (não porque seja um conceito simples, mas porque preservou, diferentemente de outros conceitos, o mesmo campo semântico em suas obras).

Na Primeira Crítica, toda referência à intuição ocorre em relação ao conhecimento. 0 conhecimento se dá quando somos conectados com um objeto, o que é possível pois nossa sensibilidade que nos fornece os meios, os modos, pelos quais nos relacionamos com os objetos a nós apresentados. A intuição kantiana não é uma estrutura mental, nem uma propriedade ou faculdade. Ela é o "que torna possível que os objetos sejam referidos pelo conhecimento". Esta intuição pode ser pura ou empírica. Será pura quando houver algo no conhecimento que independe da experiência. É graças a 
intuição pura, isto é, "a forma pura da sensibilidade ou forma pura das intuições sensíveis" (CRP $\S 1$ ) que percebo que os objetos apresentam extensão, por exemplo. Compreende-se que os objetos sejam apresentados externamente a mim, no espaço, e, sendo assim, apresentam necessariamente extensão. A intuição de espaço, como algo exterior a mim, é anterior à minha experiência com o objeto externo. Kant inclui a figura no rol das formas puras, enquanto força, divisibilidade e dureza pertencem à intuição empírica.

Uma explicação ainda mais clara encontra-se em B36 da mesma Crítica, quando Kant ao explicar a estética transcendental, designada como a ciência de todos os princípios da sensibilidade a priori, afirma: "Na estética transcendental por conseguinte, isolaremos primeiramente a sensibilidade, abstraindo de tudo o que o entendimento pensa com seus conceitos para que reste a intuição empírica." (CRP, 46 B36)

Kant prossegue dizendo que, se da intuição apartarmos tudo o que pertence à sensação, restará a intuição pura e simples, "forma dos fenômenos, que é a única que a sensibilidade a priori pode fornecer." Kant conclui o trecho com: "há duas formas puras da intuição sensível, como princípios do conhecimento a priori, a saber, o espaço e o tempo." Assim, a Estética Transcendental da Primeira Crítica conterá somente as duas formas puras, o espaço e o tempo. Todo o resto deverá supor algo empírico, como o movimento e a mudança. No tempo, diga-se não há mudança, muda o que está no tempo.

Este modo de perceber os objetos, para Kant, é "de todos os homens" embora hipoteticamente não seja de todos os seres. Delineia-se com "o espaço e o tempo são formas puras desse modo de perceber e a sensação em geral sua matéria (CRP, B59) a coerência que a semântica conceitual kantiana manterá com a sua Terceira Crítica, em que sensação, matéria empírica do fenômeno, pode nos dar o agradável, e a experiência da beleza estará fundamentada na forma.

Se nos conectamos ao mundo através da intuição fornecida pela nossa própria sensibilidade, os objetos deste só se mostram por meio dessa intuição previamente dada. 
Não há outra maneira de percebemos objetos a não ser a da nossa própria intuição, não há como termos consciência de nossa intuição sem a apresentação de objetos. Podemos fantasiar a existência de objetos não perceptíveis em nossa intuição espaço/temporal, o que, no assunto que investigamos, não é de nenhum interesse, caso fosse possível, pois precisamos de objetos que nos sensibilizem e isto só é possível ocorrer no espaço-tempo.

Assim, o objeto como experiência a posteriori sobrepõe-se à nossa intuição como possibilidade a priori, o que Kant chama de representação do fenômeno (CRP, B59).

O conhecimento kantiano está fundado na receptividade das impressões. Recebemos as representações dos objetos dados porque somos aparelhados pela intuição, pela capacidade de conhecer o objeto pela sua representação e de pensar o objeto através dos conceitos (CRP, B74).

A intuição é sempre sensível e, para haver conhecimento, deve-se fornecer um conceito correspondente. Ora, Kant afirma que intuição sem conceito é cega (CRP, B75). Então, ou temos o conceito correspondente, ou algo equivalente que o substitui. Parece não interessar a Kant a possibilidade de termos só a matéria, isto é, as sensações, sem chegarmos à representação do objeto, pela ausência de uma representação intuída. 0 exemplo musical para o exposto seria um aglomerado caótico de sons ou ainda melhor de ruídos que não entendo e nem sei de que se trata e que não posso considerar uma peça musical. 0 exemplo não é bom, pois um conjunto de ruídos pode configurar-se conceitualmente como ruídos. 0 que tentamos entender é o problema proposto por Kant de que a experiência da beleza não envolve conceitos. Como chegamos a enunciar a conclusão "isto é belo", sem um conceito para sustentar nossa conclusão? Já no início da Analítica do Belo encontramos: "Para distinguir se algo é belo ou não, referimos a representação, não pelo entendimento ao objeto com vista ao conhecimento, mas pela faculdade da imaginação (talvez ligada ao entendimento)" (CFJ § 1).

Se nos referimos à representação, há intuição que é a maneira como o objeto nos é apresentado à faculdade da imaginação e não ao entendimento. Até aqui, podemos dizer 
que a intuição de um objeto belo é cega, já que é sem conceito (CRP, B75). Ocorre que há um "talvez" no parágrafo kantiano: um "talvez ligada ao entendimento." Onde não ocorre conceito ocorre forma, e esta precisa do entendimento. Então, mesmo que a experiência da beleza não seja conhecimento no sentido conceitual estrito do termo kantiano, podemos dizer que é de algum modo cognitiva, se chamarmos cognitivo o conhecimento não conceitual que, através do entendimento compreende a forma do objeto belo. Kant admite a situação em que um objeto nos é apresentado apenas através da sensação, no caso da experiência do agradável. Neste caso, por princípio, não se trata de uma experiência de conhecimento, pois ela envolve somente o comprazimento. 0 objeto do agradável, certamente, é reconhecido conceitualmente, mas, no momento da experiência, isto simplesmente não se reveste de interesse.

O funcionamento da nossa mente, isto é, da maneira de como somos afetados, procede sempre via intuição. Se o objeto não apresenta um conteúdo formal significativo, permanecemos no nível do comprazimento pelas sensações produzidas pelo objeto (experiência do agradável). Se o objeto apresenta um conteúdo formal significativo, desencadeia-se o mecanismo reflexivo, cujo jogo das faculdades do conhecimento leva ao comprazimento da beleza. Por conteúdo formal significativo entendo uma estrutura formal do objeto que estimule as faculdades do conhecimento a compreendê-lo como algo a ser decifrado, entendido, mas que não o é nem pode ser, por não haver conceitos envolvidos. É fácil constatarmos nossa impossibilidade de transmitir em palavras a experiência de uma audição musical. Um concerto simplesmente não pode ser relatado; não há equivalente verbal para a experiência da beleza, exatamente porque, na experiência da beleza não estão envolvidos conceitos.

Um determinado objeto de experiência estética apresenta alguma estrutura formal e apresenta atrativos. Se a estrutura formal for tão simples que chega a ser óbvia, ou se o sujeito não alcança a percepção formal daquele objeto, não haverá possibilidade da experiência ir além da percepção das sensações. 
O objeto pode apresentar um conteúdo formal exclusivamente conceitual. A experiência é típica de conhecimento. Ao entrar em contato com um objeto, uma mesa, por exemplo, posso julgar que se trata de uma mesa; independentemente da variedade de formas de mesa existentes, vou encontrar, pelo meu entendimento, o conceito correspondente a uma mesa. Minha experiência se conclui: trata-se de uma mesa. Para que isto ocorra, minha mesa não precisa apresentar atrativos, ela apresenta, segundo Kant, somente a forma do fenômeno (CRP, B36). Mas a mesa pode apresentar uma pintura especial, um colorido, ou ainda apresentar uma forma elaborada de linhas de um desenho sofisticado e surpreendente. No primeiro caso trata-se de uma experiência do agradável e, no segundo, da beleza. Ambas as experiências são possíveis, desde que eu não permaneça na imediata conclusão, de que se trata meramente de uma mesa.

Por outro lado, se, no lugar da mesa considero uma peça musical, pela sua complexidade, não há um conceito correspondente à estrutura sonora. Trata-se de um objeto puramente estético. Será agradável se apresentar uma estrutura simples que me dispense de considerar sua forma, ou se tiver uma forma que eu não consiga experienciar através da minha reflexão. Será bela se o ciclo todo da reflexão sobre a forma se realizar.

$\mathrm{Na}$ relação entre a faculdade da imaginação e o entendimento, numa intuição dada, para que se encontre um conceito, a faculdade da imaginação deve fornecer a intuição correspondente ao conceito dado (neste caso pela razão). Esta dinâmica rica é esclarecida por Kant:

Assim como numa idéia da razão a faculdade da imaginação não alcança com as suas intuições o conceito dado, assim numa idéia estética o entendimento jamais alcança através de seus conceitos a inteira intuição interna da faculdade da imaginação, que ela liga a uma representação dada (CFJ 242).

No primeiro trecho da citação, uma idéia da razão pode ser um conceito prático, moral. À faculdade da imaginação não cabe nem lhe é dada a possibilidade de criar uma intuição correspondente ao conceito moral emanado da razão. Da mesma maneira, nossa razão pode produzir idéias estéticas, na 
teoria do gênio kantiana e nosso entendimento não alcançar, com os conceitos, o que a faculdade da imaginação dá conta com a intuição de uma representação correspondente à idéia original da razão. 0 edifício kantiano da mente é rico, e mesmo que o mecanismo de conhecimento ocupe toda a CRP, ele não é o mais complexo. A razão pode produzir idéias estéticas que não têm a participação do entendimento (faculdade do conhecimento) nem em sua produção nem em sua compreensão, já que não há conceitos correspondentes, mas a faculdade da imaginação produtiva apresenta uma intuição de como estas idéias se apresentam à nossa sensibilidade.

O caminho inverso é seguido pelo sujeito não produtor de idéias estéticas, mas apreciador do seu resultado. Quando uma representação nos é apresentada e não encontramos conceitos que correspondam à intuição respectiva, mas a razão se reconhece na intuição, temos a experiência do sublime.

Kant afirma que, para cada conceito, deve haver a intuição respectiva:

A prova da realidade de nossos conceitos requer sempre intuições. Se se trata de conceitos empíricos, as intuições chamam-se exemplos. Se conceitos do entendimento puro, elas se chamam esquemas (CFJ 254).

Claramente, não haverá realidade objetiva para os conceitos puros do entendimento, a não ser que eles sejam acompanhados de intuições - sempre sensíveis -, embora possa haver, não intuição racional, mas conceitos racionais, ou idéias, que não tem nenhum correspondente sensível.

Intuição é a representação da faculdade da imaginação, originária, em duas direções possíveis: externa para interna e vice-versa. Na primeira, quando encontramos algo que altera nosso estado como um objeto exterior a nós; a intuição é figura, forma, Gestalt, conjunto coerente dos elementos que constituem o objeto. A segunda direção, interna para externa, é seguida pelos artistas em suas criações e pelos gênios em suas obras belas. É igualmente a representação materializada de idéias estéticas originadas na razão sem conceitos equivalentes, por isso impalpáveis e indefiníveis. 
Se intuições puras são formas conhecidas a priori sem o uso de qualquer percepção real, e intuições empíricas são percebidas através da sensação, a posteriori, pode-se perguntar o que na arte em geral e na música em particular pertence à intuição pura. A possibilidade de sons organizados estruturalmente proporcionar-nos prazer pertence à intuição pura. Como isto se realiza, com que meios, as diferenças relacionadas às diferentes épocas históricas e a geografia sóciopolítica, tudo isso caracteriza a intuição empírica. A base de organização de sons que chamamos música é a intuição pura e o fato dos seres humanos, independentes de cultura e localização geográfica em algum momento e de alguma maneira produzirem algo que podemos chamar de música, tornando quase universal este fenômeno, é a intuição empírica.

\section{Os juízos e a reflexão}

O grande problema kantiano dos juízos está resumido na pergunta: "Como são possíveis os juízos sintéticos a priori?" (CRP B 73). A pergunta é repetida na CFJ, no § 36 "Do problema de uma dedução dos juízos de gosto", onde Kant se pergunta sobre o prazer e a ausência de conceito:

Como é possível um juízo que, simplesmente a partir do sentimento próprio de prazer num objeto, independentemente de seu conceito, ajuize a priori, isto é sem precisar esperar por assentimento estranho, este prazer como unido à representação do mesmo objeto em todos os outros sujeitos? (KANT, CFJ 148)

$\mathrm{Na}$ CRP, a frase citada inicialmente constitui o nó central da filosofia crítica de Kant, que, na Primeira Crítica, na Estética Transcendental é "uma ciência de todos os princípios da sensibilidade a priori (CRP B35)", portanto, uma ciência de tudo o que nos é apresentado como objeto na nossa sensibilidade, mas cujos princípios não necessitaram de experiências para existir.

$\mathrm{Na}$ CFJ a repetição da pergunta adquire um significado ainda maior, pois coloca a questão central do gosto no mesmo nível da questão do conhecimento em geral. Assim, o juízo de gosto assume um status semelhante ao do juízo do 
conhecimento, mesmo sem estar fundamentado em conceitos e baseado num simples sentimento de prazer, algo muito mais subjetivo do que o conceito. Com a CFJ, a concepção kantiana do homem iluminista está completa: ele conhece, aprende, cria leis práticas para si mesmo e aprecia a beleza.

Que o prazer sendo mais subjetivo que o conceito, esteja no fundamento do juízo do gosto, é o problema central da CFJ. Kant tem o cuidado em não utilizar o termo fundamento, pois, como ele esclarece, "é simplesmente a partir do sentimento próprio de prazer" que ocorre o juízo do gosto, e, no mesmo trecho, "pode-se também ligar imediatamente a uma percepção um sentimento de prazer (ou desprazer) e um comprazimento" (CFJ 147). Nota-se o cuidado kantiano na utilização dos termos "a partir" na primeira frase e "ligar" na segunda, com o que não se pode concluir que o prazer seja o fundamento do juízo de gosto. Na segunda citação, é curioso

52 observar que Kant trata sentimento de prazer e comprazimento, à primeira vista como dois eventos distintos. No texto original lê-se: "mit einer Wahrnehmung kann aber auch unmittelbar ein Gefühl der Lust (oder Unlust) und ein Wohlgefallen verbunden werden." 0 verbo kann foi traduzido na edição portuguesa da CFJ por "pode-se", como esperado. Mas, poderíamos perguntar que se Kant quisesse dizer duas coisas diferentes, teria utilizado können e a tradução ficaria: "Mas podem também ligar-se imediatamente a uma perceção um sentimento de prazer (desprazer) e um comprazimento." Por outro lado por que usar "ein Gefühl und ein Wohlgefallen?" Seria porque os termos se complementam? Enquanto Gefühl apresenta um significado de sentimento básico, próximo de uma percepção, Wohlgefallen seria um sentimento mais interno não apenas de sentir algo, mas sentir paz, quietude?

A questão que nos trouxe ao trecho é a do juízo, especificamente do denominado juízo estético, que, não sendo "um simples juízo de sensação", é um juízo formal de reflexão. Neste caso, o comprazimento não é apresentado como fundamento do juízo, mas como "necessário a qualquer um." 0 que estará no fundamento do juízo é algo como um princípio a priori, mesmo que subjetivo. Da mesma maneira como transcorreu o tratamento na CRP, trata-se aqui de encontrar 
quais princípios a priori da faculdade de juízo pura são encontrados nos juízos estéticos.

No mesmo parágrafo, Kant esclarece que "os juízos de gosto (...) ultrapassam o conceito e mesmo a intuição do objeto e acrescentam a esta, como predicado, algo que jamais é conhecimento, a saber o sentimento de prazer (ou desprazer)" (CFJ 149).

Este é o ponto. A valorização por parte de Kant ao juízo estético de gosto que "ultrapassa o conceito" parece-nos, não tem sido reconhecida pelos estudiosos da estética kantiana. Alcançar o conceito era a pretensão do conhecimento ao longo de toda a CRP. Ora, o juízo de gosto é mais que o conceito e mesmo mais que a intuição correspondente do objeto, pois ganhamos com essa experiência o prazer que deve valer para todos. 0 juízo de gosto, mesmo sem levar ao conhecimento, é maior que este e, ao afirmar que o prazer é como um predicado, Kant se coloca numa situação sui generis na história da estética, a do autor que, rigorosamente formalista, valoriza o prazer (subjetivo) dessa maneira tão intensa.

O problema do juízo de gosto, e frequente objeto de crítica dos comentaristas de Kant, é que o juízo de gosto é empírico. Tomado desta maneira, próprio Kant o chamaria de "simples juízo empírico" (CFJ 37). Mas o que seria a priori no juízo de gosto e especialmente, o que seria a priori no juízo do gosto musical, isto é na produção e no ajuizamento da música bela? 0 problema é o mesmo de toda a estética transcendental da CRP. Diz Kant:

Referimo-nos a intuições puras a priori, o espaço e o tempo. Nestas intuições, quando num juízo a priori queremos sair do conceito dado, encontramos aquilo que pode ser descoberto a priori, não no conceito, mas certamente na intuição correspondente (CRP B 73).

No juízo de gosto não há conceito, há prazer, portanto o prazer, enquanto conseqüência da experiência, não é $a$ priori. 0 que na experiência musical pode ser a priori é a base mais simples da organização musical. O que está na intuição, no caso musical, no tempo como intuição kantiana, é a possibilidade dos sons poderem ser sustentados, sucessivos e simultâneos, no tempo. Kant chama esses três os modos do tempo (CRP 
B219). Destes modos do tempo provêm as três regras de todas as relações de tempo dos fenômenos e "essas três regras precedem toda a experiência e tornam-na possível" (CRP B219). Sendo assim, o que é a priori na música a base dos modos do tempo que fazem da música um fenômeno temporal. 0 ritmo, tomado como a base inicial da organização musical contém os três modos kantianos. Os sons podem ser mantidos (sustentados), um som pode ocorre após outro (sucessão) e dois ou mais sons podem ocorre ao mesmo tempo (simultaneidade).

A gigantesca possibilidade de combinações dos três modos do tempo proporciona as caracterizações rítmicas culturais da produção musical em geral. A melodia e a harmonia (consideradas como variações da altura dos sons) seriam resultados empíricos, portanto a posteriori. Sobre esta questão, escreve Kant nas "Preleções de Lógica (Philippi)" 4:

Na música, a harmonia é a própria beleza e [é] para o entendimento; a melodia, porém, o estímulo ou a sensação. Aquela é universalmente válida e inalterável;esse, o estímulo, é diverso segundo a diversidade dos sujeitos (V. Lo/ Philippi, AA 24:352).

No mesmo escrito, um pouco antes:

Na música, o melódico ou o tinir dos sons é a matéria; mas a forma dos mesmos consiste na variação harmônica desses sons. No que concerne à matéria ou ao tinir, a um, então, pode ser agradável isto, a outro, o instrumento. Pois, nisso, ele depende da sensação, que é diferente nos diferentes sujeitos. Só que no atinente à forma da música, um concerto que é harmônico tem então de bem soar a todos (V. Lo/ Philippi, AA 24:348-349).

A questão apresentada por Kant centraliza-se em: "mas a forma dos mesmos consiste na variação harmônica desses sons". Pergunta-se se uma melodia já não apresenta em si mesma uma variação harmônica, isto é, se o suceder de notas não contém sempre uma variação harmônica, se a melodia não

\footnotetext{
${ }^{4}$ Agradeço ao Prof. Ubirajara Rancan a indicação e tradução deste trecho da Lógica Philippi.
} 
contém a harmonia e assim sendo, a melodia também seria bela e a sensação que é diferente nos sujeitos, estaria contida no som isolado (não consitituinte da música) e no timbre (no instrumento). ${ }^{5}$

Kant considera também não o prazer, mas "a validade universal deste prazer (CFJ 150), que é representada a priori num juízo de gosto como "válida para qualquer um".

Esse é o juízo que pode ser resultado de uma experiência, portanto, empírico mas que resulta em prazer. Para considerar que o objeto que me proporcionou prazer é um objeto belo, devo "postular aquele comprazimento em qualquer um como necessário." A conseqüência dessa proposição kantiana é que somos, pelas nossas faculdades superiories, portadores de "um sentimento humano comum" e "considerado o mínimo que sempre se pode esperar de alguém que pretende o nome de homem" (CFJ 157).

O sentimento humano comum é apresentado por Kant já no título do $\S 40$ como "uma espécie de sensus communis". Kant critica a ambiguidade do termo comum que pode ser entendido por vulgare. Sua definição neste parágrafo de sensus communis é: "uma faculdade de julgamento, que na sua reflexão considera em pensamento (a priori) o modo de representação de todo o outro, como que para ater o seu juízo à inteira razão humana" e com isso não cair na ilusão de que condições privadas subjetivas sejam tomadas por objetivas e assim influenciem o juízo. 0 ser dotado de sensus communis será capaz de abstrair da matéria (sensação) e fixar-se "nas peculiaridades formais de sua representação ou do seu estado de representação." Kant julga natural que sejamos dotados de tal senso comum. Comprova-se o senso comum quando conseguimos abstrair do atrativo e da comoção em um juízo que, apesar disso, deve servir de regra universal. No entanto, no § 20 Kant chama de sentido comum (gemeine Sinne) o princípio mesmo subjetivo, o qual determina através de sentimento (não de conceitos), mas de modo universalmente

5 Um exemplo magistral que ilustra esta questão é dado pelas seis suítes para Violoncello solo de J.S. Bach (BWV 1007-1012). 
válido, o que apraz (CFJ 64) e para nossa surpresa "é essencialmente distinto do entendimento comum, que às vezes também se chama senso comum (sensus communis): neste caso ele não julga segundo o sentimento mas sempre segundo conceitos."

Parece claro até aqui que senso comum é a faculdade de julgamento na reflexão, comum aos homens. 0 sentido comum seria um refinamento do senso comum. 0 primeiro é utilizado nas necessidades gerais de ajuizamento reflexivo e o segundo especificamente na situação de olharmos para o nosso próprio sentimento (não de conceitos) de modo a entendermos e pressupormos a universalidade de tal sentimento, desse modo válido para todos. O sentido comum é a base da existência do juízo de gosto, e assim, o senso comum deve ser esperado de todos que se autodenominam homens; mas estar incluido no rol dos homens não garantirá o juízo de gosto. Para

56 isto é necessário um sentido comum. Mesmo o senso comum deverá desenvolver-se, pois Kant considera que as máximas do entendimento: (1) pensar por si; (2) pensar no lugar de todo o outro e (3) pensar sempre de acordo consigo próprio, apresentam dificuldades diferenciadas, pois a terceira "é a mais difícil de alcançar." De maneira surpreendente, o problema colocado pelo próprio Kant no texto da Terceira Crítica entre senso comum e sentido comum acaba brilhantemente resolvido por ele mesmo numa pequena nota, portanto, fora do corpo do texto principal : "Pode-se designar o gosto como sensus communis astheticus e o entendimento humano comum como sensus communis logicus" (KANT, CFJ 160 - Nota 10)."

A conseqüência disto para o estudo da estética musical de base kantiana é que se pode dizer que, se o senso comum lógico é passível de formação e desenvolvimento, o senso comum estético musical deverá ainda mais estar sujeito à educação e às oportunidades de estudo, por tratar-se de um campo de conhecimento (termo evitado por Kant que só reconhece conhecimento como o conceitual) especial cujo conteúdo escapa e se distancia do conhecimento lógico e exige formação específica.

Um resumo das questões sobre o juízo encontra-se na Introdução da CFJ: "A faculdade do juízo em geral é a faculdade 
de pensar o particular como contido no universal" (CFJ IV). 0 juízo trata assim de conceitos, pois pensa-se por conceitos. 0 problema é, para um certo objeto dado, encontrarmos um conceito que lhe corresponda.

Antonio Marques, no prefácio da edição portuguesa da CFJ (KANT, 1992b, p. 17) diz que:

As belas formas e as formas orgânicas exercem, diríamos, uma pressão para a reflexão. Por outras palavras, obrigam à escolha de pontos de vista que implicam da parte do sujeito, uma alargamento das perspectivas fundamentais --- isto é, do sistema ou tópica das categorias.

A herança da CRP é ampliada pela reflexão na CFJ, justamente num campo sem conceitos e carregado de subjetividade do prazer. 0 juízo reflexionante ocorre quando, sendo dado o particular, descobre-se a regra universal sob a qual este pode ser subsumido. Na música, uma simples melodia, uma seqüência de sons com nexo entre si corresponde ao particular. A regra universal é a constatação de que posso, da mesma maneira, obter inúmeras melodias. Como ouvinte, é esperado em todos, que as diferentes melodias (o âmbito universal) sejam percebidas como tendo por suporte o mesmo princípio particular de seqüência de notas.

Kullenkampff (in ROHDEN 1992, p. 10) esclarece: "E os juízos correspondentes, que enunciam como me sinto diante de um determinado objeto que me afeta, são juízos estéticos." 0 autor em seu artigo, compara juízos lógicos com estéticos, afirmando que juízos estéticos possuem como critério decisivo tão somente a razão subjetiva de determinação do nosso sentimento de prazer e desprazer. Mas se a determinação do nosso sentimento de prazer e desprazer está na consciência que temos de que nossas faculdades de conhecimento estão em jogo, o critério decisivo não pode ser tão somente a razão subjetiva.

A constatação do jogo das faculdades torna nosso juízo mais objetivo, embora não apresente a mesma objetividade de um juízo lógico, já que não envolve conceito, mas dá-lhe o status de um juízo intermediário, o de um conhecimento sem conceito, um conhecimento formal, mais profundamente objetivo que o juízo de sentido estético. Neste, a sensação é 
imediatamente produzida pela intuição empírica do objeto, assim, trata-se de um juízo que não merece a denominação de juízo já que, por referir exclusivamente ao agradável, pertence mais à faculdade da apetição, é um juízo prático. Já o juízo de reflexão estético é aquele que o jogo harmonioso das duas faculdades de conhecimento, imaginação e entendimento, efetua no sujeito, na medida em que, na representação dada, a faculdade de apreensão de uma e a faculdade de exposição de outra são mutuamente favoráveis uma à outra, proporção esta que, nesse caso, efetua por essa mera forma uma sensação, que é o fundamento de determinação de um juízo, que por isso se chama estético e, enquanto finalidade subjetiva (sem conceito), está vinculado ao sentimento de prazer" (KANT, 1995, p. 61).

Kant reconhece a situação diferenciada do juízo de reflexão estético, mas não o denomina jamais juízo de conhecimento formal, isto é, conhecimento sem conceito. Em 58 outros momentos, Kant acena com a possibilidade, de o juízo estético conter algo do lógico como no trecho:

Ele falará, pois, do belo como se a beleza fosse uma qualidade do objeto e o juízo fosse lógico [...] conquanto ele seja somente estético e contenha simplesmente uma referência da representação do objeto ao sujeito; já que ele, contudo, possui semelhança com o lógico (...) (CFJ 18).

Kant, porém, não esclarece onde reside essa semelhança. Vemos que o juízo estético precisa da participação do entendimento, pois, sem o entendimento, o juízo (como o do agradável) não pode ir além de constatar a sensação que o causou. Mas precisar do entendimento não significa fundamentar-se em conceitos. Esta é a razão de tendermos a considerar o juízo estético um juízo cognitivo sem conceito. Nesse sentido se entende porque o juízo estético é uma ponte, uma passagem que liga o domínio estético ao conceitual, enquanto que o juízo do sublime liga o estético ao prático, com a participação da razão.

Na mesma CFJ 156, encontramos:

A representação sobre verdade, conveniência, beleza ou justiça, jamais poderia vir-nos ao pensamento, se não pudéssemos elevar-nos sobre os sentidos até as faculdades de conhecimento superiores. 
A inclusão da beleza junto da verdade e justiça mostra como Kant não precisa apresentar justificativas para inclui-la no rol dos conceitos mais preciosos de sua filosofia e, assim, propor-nos um tratamento de igual importância em seu estudo e consideração. Já nas Duas Introduções (KANT, 1995, p.41) Kant afirma que: "e nessa medida são consideradas apenas na relação ao sentimento de prazer e este último absolutamente não é nenhum conhecimento, nem o proporciona, embora possa pressupô-lo como fundamento de determinação."

Fica clara sua preocupação em realçar que o sentimento de prazer não pode ser conhecimento. 0 que não está dito, é, que o sentimento é só uma parte do ajuizamento estético e que as outras partes envolvidas podem sugerir algum tipo de atividade que de alguma forma se assemelhe ao conhecimento ou que, ao menos, seja uma atividade cognitiva. Esta pressuposição forneceria a permissão de se falar de cognitivo sem conhecimento conceitual. 0 envolvimento de juízo, reflexão e faculdades de conhecimentos superiores permite-nos pensar desta maneira. Kant teria algo semelhante em mente, ao afirmar que:

Prazer é um estado da mente, no qual uma representação concorda consigo mesma, como fundamento, seja meramente para conservar esse próprio estado (pois o estado de poderes da mente favorecendo-se mutuamente em uma representação conserva a si mesmo) ou para produzir seu objeto. No primeiro caso, o juízo sobre a representação dada é um juízo de reflexão estético. No segundo, é um juízo estético patológico ou estético-prático. (KANT, 1995, p.67).

Observamos que Kant, ao utilizar a expressão juízo de reflexão estético não esclarece se a representação é de um objeto belo, mas deve sê-lo, pois, está inclusa a reflexão. Para o momento, é esclarecedor que Kant considera a possibilidade de juízo estético prático. Pensar o sublime como um juízo estéticoprático, passa a ser uma possibilidade, pois no sublime, o verdadeiro objeto é a produção no sujeito do sentimento do sublime frente a objetos ou situações.

As faculdades superiores e a constituição do ânimo apresentam na Terceira Crítica um veio promissor, para a 
compreensão do fenômeno artístico. Rohden (1992, p. 127) esclarece que:

Kant entendeu o Gemüt (ânimo) como o princípio unificador das diversas faculdades em relação recíproca, tendo sentido transcendental cognitivo e também estético vivificante das faculdades de conhecimento.

Ainda, no mesmo texto (ROHDEN, 1992, p. 130), a reflexão é a apreensão de um fenômeno em sua forma, o ajuizamento de uma coisa de um ponto de vista que supera a perspectiva individualista e o ajuizamento sob a forma do todo.

A relação entre estas fases e o sentimento que fundamenta um juízo estético merece um estudo mais aprofundado. Se entendermos a reflexão como passos das faculdades de conhecimento envolvidas neste processo, classificaremos a estética kantiana como mais formalista do que se valorizarmos o sentimento como fundamento. No primeiro caso, o qual tendemos a adotar, o sentimento é uma consequência do processo de reflexão.

O juízo estético do belo, é o que é, porque mesmo utilizando-se das faculdades de conhecimento não leva a conceitos, mas ao sentimento resultado da reflexão. Isto me permite entender que na música, meu sentimento de admiração da beleza é separado da reflexão. Isto é, meu prazer ao ouvir música é uma parte do fenômeno; minha consciência da sua beleza é uma outra. Na consciência da beleza coloco um valor. Por isso diz-se, "que música boa"! É a superação da perspectiva individualizada que possibilita a universalidade do juízo e não o sentimento.

Quanto ao papel das faculdades de conhecimento na reflexão, a faculdade da imaginação é uma faculdade produtiva. Ela consegue produzir representações sem a presença do objeto, e, consegue formar representações sem correspondência a objetos, o que é uma característica da representação estética. Na música isto ocorre exemplarmente. A organização sonora não se caracteriza como objeto, dado seu distanciamento do conceito.

Mas a mesma organização nos proporciona uma representação diferente e até distante do princípio sonoro 
físico, entendido aqui como sensação. 0 conjunto das sensações dos sons, a massa sonora não é música. Música é a representação construída na mente a partir do conjunto das sensações sonoras organizadas de tal forma que as próprias sensações deixam de ser consideradas.

\section{Referências bibliográficas}

BOURDIEU, P. La Distinction. Paris: Les Éditions de Minuit, 1979.

CASSIRER, E. Kant, vida y doctrina. México: Fondo de Cultura Economica, 1948.

CAYGILL, H. Dicionário Kant. Rio de Janeiro : Jorge Zahar, 2000.

GATZ, F. M. Musikästhetik in ihren Hauptrichtungen. Stuttgart : Ferdinand Enke, 1929.

GIORDANETTI, P. Kant und die Musik. Würzburg : Königshausen u. Neumann, 2005.

HANSLICK, E. Do belo musical. Campinas: Ed. Unicamp, 1989.

KANT, I. Antropologia de um ponto de vista pragmático. São Paulo: Iluminuras, 2006. 1992a.

A religião nos limites da simples razão. Lisboa: Edições 70, . Crítica da Faculdade do Juízo. Lisboa: Imprensa Nacional, Casa da Moeda, 1992b.

. Crítica da Razão Prática. São Paulo: Martins Fontes, 2002. $\overline{1989 .}$. Crítica da Razão Pura. Lisboa: Fundação Calouste Gulbenkian, Moeda, 1985.

Dissertação de 1770. Lisboa: Imprensa Nacional, Casa da . Duas Introduções à Crítica do Juízo. São Paulo: Iluminuras, 1995.

Fundamentação da Metafísica dos Costumes. Porto: Porto Editora, 1986.

. Lógica. Rio de Janeiro: Tempo Brasileiro, 1999.

. Manual dos cursos de Lógica Geral. Ed. Unicamp, 2003. 
Observações sobre o sentimento do belo e do sublime. Papirus, Campinas, 1993.

—_. Werke in sechs Bänden. Darmstadt :Wissenschaftlichen Buchgesellschaft, 1998.

KIVY, P.Introduction to a Philosophy of Music. Oxford, USA: Clarendon Press, 2002.

LACROIX, M. O culto da emoção. Rio de Janeiro: José Olympio Editora, 2006.

LISTOWEL, Conde de. História Crítica de la Estética Moderna. Buenos Aires : Editorial Losada, 1954.

LOPARIC, Z. A semântica transcendental de Kant. Coleção CLE, № 29, Campinas: Unicamp, 2002.

ROHDEN, V. (Org). 200 Anos da Crítica da Faculdade do Juízo de Kant. $\begin{array}{llll}\text { Porto Alegre: } & \text { Ed. }\end{array}$ 